Article

\title{
Low-Carbon Tourism-Technical, Economic and Management Project of a Greenway, for Enhancing Inner Areas of the Cilento National Park, Italy
}

\author{
Giacomo Di Ruocco ${ }^{1, *(\mathbb{D})}$, Luis Palmero Iglesias ${ }^{2}$, Begoña Blandón ${ }^{3} \mathbb{C}$ and Roberta Melella ${ }^{1}$ \\ 1 Department of Civil Engineering, University of Salerno, 84084 Fisciano, Italy; rmelella@unisa.it \\ 2 Architectural Construction Department, University Politècnica of València, 46022 València, Spain; \\ lpalmero@csa.upv.es \\ 3 Architectural Construction Department 1, University of Seville, 41004 Sevilla, Spain; bblandon@us.es \\ * Correspondence: gdiruocco@unisa.it; Tel.: +39-3339040747
}

Received: 15 October 2020; Accepted: 27 November 2020; Published: 30 November 2020

\begin{abstract}
In the light of recent emergencies represented by climate change and global warming, with the consequent policies to reduce greenhouse gas emissions, this research aims at offering a response to the need for decarbonization of anthropization processes of territories, on a building and urban scale. This study elaborates a methodology, according to an integrated qualitative-quantitative approach, which combines the strategic need for sustainable mobility with the need to enhance the value of natural and environmental interesting places, typical of the Mediterranean area and in particular the ones which represented the heart of Magna Graecia. This strategy is implemented through a growing mobility offer in recent years: sustainable cycling tourism, which is included in the wider and more widespread strategic action of greenways. However, these strategies do not often meet the interests of the public administration, which is refractory to face great costs in exchange for a hypothetical return on investment, in the long term; the result is the abandonment and degradation of territories characterized by a remarkable naturalistic, landscape and environmental value. The aim of this study, therefore, is to provide operators in the sector (public administration, Cilento National Park Authority, economic operators, etc.) with a decision-maintenance tool, through the definition of priority criteria for interventions, according to an economic sustainability approach of the intervention and adopting an integrated qualitative-quantitative methodology. The intervention, as a whole, involves a cycle path of about $600 \mathrm{~km}$, passing through 70 countries of the territory. Therefore, assuming the impossibility of being carried out at the same time, as a whole, it has been divided into 23 functional lots: the methodology intends, precisely, to define the priority and necessity criteria that determine the classification of importance of the 23 routes (sub-interventions), identified in this study.
\end{abstract}

Keywords: sustainable development; low-carbon tourism; greenway; sustainable mobility; cycle tourism; valorisation; conservation; technical and economic feasibility

\section{Introduction}

The aim of this research is the valorization of abandoned areas through sustainable mobility strategies. As far as depopulation is concerned, demographic change is one of the main policy challenges in Europe. More than $40 \%$ of European regions are losing their population and the population of predominantly rural regions is expected to decrease by 7.9 million by 2050 [1].

About sustainable mobility, this is one of the main objectives of the Connecting Europe Facility (CEF) for the period 2021-2027. As a key financing mechanism for investments in EU transport systems, 
the CEF will contribute to the decarbonization of the mobility sector and thus to the achievement of the 2050 climate neutral target [2]. One of its priorities is to develop a European transport network, while helping the European Union's (EU's) transition to connected, sustainable, inclusive, safe and secure mobility.

\subsection{Strategies for the Enhancement of Shrinking Regions}

In 2012, in Italy, a National Strategy for a "Domestic Areas" development was enhanced, starting from the awareness that a prevalent part of the Italian territory (about sixty percent of the national territory) is characterized by the presence of small municipalities, far from the essential services—such as school, health and mobility—whose marginalization is therefore an important national issue [3]. The National Strategy for Inner Areas (SNAI) aims to redevelop fragile territories, far from the main supply centers of essential services and too often abandoned to themselves, covering, however, $60 \%$ of the entire national territory, $52 \%$ of the municipalities and $22 \%$ of the population. The National Strategy aims to intervene on these sites, investing in the promotion and protection of the territory and local communities' wealth, enhancing their natural and cultural resources, creating new employment circuits and new opportunities; shortly, counteracting the "demographic hemorrhage." The areas selected by the SNAI are seventy-two; they include a total of 1077 municipalities for about 2,072,718 inhabitants [4].

In the field of building and environmental recovery technology, the combination of resilience/vulnerability [5] is an effective key to understand the phenomena affecting these areas. Inner areas, in fact, can be considered "resilience reservoirs": where they are not altered due to land use operations (wind farms, power lines, etc.) or uncontrolled reconstruction following calamitous events, they mostly keep their material identity intact and constitute a "latent territorial resource" that offers high development potential [6]. However, inner areas are characterized by high vulnerability because their material culture, in their close relationship between natural resources and anthropic activity [7], is characterized by a fragile heritage, by "simple" building qualities, subjected to natural risks and anthropic pressures, to the absence of economic prospects due to the presence of a predominantly elderly population, to an agricultural and natural landscape vulnerable to the pressures of the economic market (importation of more competitive products, exploitation of unprofitable soils, etc.). The strategy, which has experimentally involved 23 pilot areas on which interventions will be concentrated in the period 2014-2020, is characterized by an integrated territorial development trajectory, where economic, social, political and institutional diversity maximizes both local and aggregate potentials for economic development [8]. Similarly, the United Nations Agenda 2030 is based on the reactivation of synergies between territory and communities to achieve inclusive, safe, resilient and sustainable human settlements [9].

\subsection{Sustainable Mobility and Eco-Tourism}

Sustainable mobility and in particular cycling, is encouraged by current policies, both at international and national level. The policy recommendations issued by the European Committee of the Regions in 2017 [10] highlight the need to promote, within territorial planning tools: the improvement of pedestrian and bicycle accessibility to public transport stops, the implementation, at the system's interchange points, of spaces and parking areas—safe, attractive and accessible to all—for bicycles and possible bike sharing services.

With a view to sustainable mobility, the greenways represent a routes system dedicated to non-motorized traffic that can connect users with the territory resources (natural, agricultural, landscape, historical-cultural, etc.).

One of the activities certainly compatible with the greenways type is cycling tourism [11]. The activity of cycling tourism is recognized as a sustainable tourism mode [12] and as a new way of enjoying tourism [13]. It is rapidly spreading, in recent years, as an alternative method of travelling or spending free time with the possibility of visiting, observing the landscapes along the way and 
immersing oneself in the chosen places, perceiving the context in a sensorial way; it can also be a form of aggregation among people who, through quiet bike rides, have the possibility of sharing and exchanging experiences by spending pleasantly time together [14].

Some studies show that cyclists' motivations to arrange cycling holidays are due to the pleasure of cycling as a form of sport and relaxation, in order to perceive their own sense of freedom and completeness; it is also considered a way to stay fit, to be in contact with nature and the possibility to explore places, admire and take pictures of landscapes in a completely different way from travelling usual standard methods [15]. Recent research carried out by the Centre for Transport and Sustainable Tourism of the University of Breda, in the Netherlands [16], shows that cyclists are a category of users who prefer places and routes away from mass tourism and who are inclined to spend more, being generally people with a good living standard. It is estimated that a cyclist spends an average of about twenty-five euros a day on food and services, compared to a traveler who moves by car and spends only seven euros a day; this is because those who travel by car take everything they need with them, while a cyclist, having little space available, has to get what he needs on the way. This data shows that increased cycling tourism can be an important tool for the territory economic development [17].

\section{State of the Art}

There is an extensive literature about Greenways' multiple benefits and effects, in terms of positive impacts on social, economic and environmental sustainability. Many scientific studies have been developed focusing on the multiple positive impacts of these types of infrastructure, according to multiple aspects: in terms of reduction of carbon emissions in the transport network [18-20]; improvement of air quality [21]; improvement of life quality and well-being [22-24]; sustainability of infrastructures $[25,26]$; better inclusion in the environmental context and landscape enhancement [27]; opportunities for 'slow' use of the naturalistic-environmental landscape [28]; strategic potential for economic, environmental, social development [29,30]; appropriate allocation of economic investments [31].

\subsection{Reducing Carbon Emissions in the Transport Network}

In particular, Manton et al. (2014) $[18,20]$ focus the study on reducing the carbon footprint of green roads. Through the analysis of a study case of a greenway in Ireland, the authors describe a methodology for the calculation of carbon costs and savings associated with the construction of cycle paths. By carrying out a life cycle assessment, with reference to the greenway 20-year life projection, the authors quantified the embedded carbon reduction between an asphalt cycleway and a green cycleway, taking into account the carbon contained in construction materials and motor vehicles. Douglas et al. (2018) [19] assessed the causal relationship between an urban greenway, motorized travel behavior and environment outcomes and provided the first quantification in the literature of the effect of a greenway on transportation-related GHG emissions and energy use. With reference to the study case in Vancouver (Canada), they estimate the reduction in greenhouse gas emissions, due to daily transport, to be $20.90 \%$ after the construction of the Comox Greenway. The analysis results indicated that the effects of the greenway differed by proximity: the emission reduction associated with the greenway increased with distance, gradually from 100 to $200 \mathrm{~m}$ before reaching an upper limit at $300 \mathrm{~m}$.

\subsection{Improvement of Air Quality}

Hao et al. (2015) [21] highlight how air pollution represented by PM2.5 (particulate matter 2.5 micrometers) should influence urban planning and transport network models. To this end, the community greenway offers us a new way of thinking about how to make the cities of the future a livable space that combines nature and cities. That is, connecting community parks, green road areas, schools and the main places of activity for residents with community greenery and connecting urban open spaces to form a network of corridors, so as to disperse, dilute, mitigate and degrade PM2.5. 


\subsection{Improving Quality of Life and Well-Being}

The goal of Shahani (2013) [22] is life quality and how it can be achieved in an ecological way based on sustainable development. In the Three Green Streets of Tehran (Iran) some particular characteristics that are linked to the improvement of life quality are examined by people with questionnaires. The main result of this research is the classification of key characteristics of life quality and the proposal of strategies and solutions to develop it in the urban environment. The aim of the document is to demonstrate the importance of greenway towards the improvement of sustainable development in urban areas. The case of greenways in Tehran aims to present the results obtained in the field of urban planning and reception of quality of life factors. The paper by Fabris and Semprebon (2019) [23] analyses how, at the beginning of the 21st century, Milan has profoundly transformed itself into a mere service center. The change has also affected its territory acting on its industrial areas and logistic complexes, which were places without use punctuating its urban fabric. The focus of the paper is about Milan's public greenery history and suggests that the town can be seen as a cluster that creates a wide network of green roads on a urban and suburban scale. In order to improve life quality of its citizens, over the last five years the new administration's new policy has favored the redevelopment of abandoned areas ("Re-shaping Milan" 2015 and the "Re-shaping Milan" actions, underway in 2018, developed with the Milan Polytechnic) and has asked the State Railways (Trenitalia) to "return" six unused railway stations on the city's territory to the city. Dallat et al. (2013) [24] describe how the potentially feasible increase in physical activity levels achieved through a urban regeneration project could be a cheap way to increase physical activity levels. This comes at a time when potential environmental changes, that may affect health, have attracted policy makers' attention, as it made clear that individual, social and physical environmental factors play all an interrelated role in promoting physical activity. The study therefore provides a timely addition to the evidence base to inform policy and practice in this area, showing that if $10 \%$ of those classified as 'inactive' became 'active', a total of 886 accidents $(1.2 \%)$ and 75 deaths $(0.9 \%)$ from ischemic heart disease, type 2 diabetes, stroke, colon and breast cancer could be prevented by 2050 in the Greenway population.

\subsection{Infrastructures Sustainability}

According to Zareba (2017) [24] Greenways constitute linkages across landscape patches in different planning scales (city, suburbs, exurbs and hinterland scales) for various uses compatible. They help to assist in the revitalization of urban derelict lands and to change former industrial centers into mixed-use public open spaces oriented to tourism and recreation. The objectives of the paper are: to explore the concept of multi-function of greenways through studies of selected examples of metropolitan areas and to present opportunities to implement urban greenways in local and metropolitan scales. The case studies are analyzed in terms of: location and geographical environment, neighborhood land, ecological, social and other functions (with emphasize on environmental sustainability). The research results include recommendation for ecologically and socially sensitive development of greenways as the alternative for sustainable transport in highly urbanized environments. Zawawi et al. (2020) [25] describe how greenways can be a constituent of sustainable urban mobility (SUM) systems that reduce car dependence while simultaneously having positive environmental and social co-benefits. The paper begins by providing a brief background on the harmful effects of car dependency. A chronological review of the greenways evolution as a typology, divided into five generations starting from pre-1900 until today, demonstrates how various economic, political, environmental and social factors have shaped blue-green corridors in different cities, mainly in English-speaking countries. The discussion then focuses on the integration process between greenways and SUM planning, as well as highlighting some of the planning challenges and opportunities of (re)developing greenways to support as non-motorized transport corridors. By critically analyzing the evolution of greenways in relation to urban mobility and their integration process, this paper supports green space, transport and design professionals to work toward a shared vision of sustainable cities. 


\subsection{Better Integration in the Environmental Context and Landscape Enhancement}

Quattrone et al. (2017) [27] identify the appropriate road infrastructure, available in the former Province of Syracuse (East Sicily-Italy), for building greenways networks that will best contribute to the valorization of their surrounding territory. This work assigns great importance to landscape features as factors of tourist and cultural attraction. We have used the multi-criteria analysis associated with GIS. We have weighed and mapped numerous indicators to define the territory's infrastructural, landscape, cultural and tourist resources, meaning those able to increase the use of the territory and/or that determine attractiveness for the population. Through GIS analysis they develop numerous intermediate maps, whose information helped us to draw up the final map illustrating the suitability of the existing infrastructures that could be useful while planning of a greenway network. Such infrastructures could be the subject of specific plans or detailed projects aimed at enhancing the pre-existing resources of a rural territory.

\subsection{Opportunities for 'Slow' Enjoyment of the Naturalistic-Environmental Landscape}

Dickinson and Lumsdon (2010) [28] explain slow travel as a holiday where air and car transport is rejected in favor of more environmentally benign forms of overland transport, which generally take much longer and become incorporated as part of the holiday experience. The book provides a cutting edge critique of the 'upstream' drivers to unsustainable tourism. The authors illustrate their approach through a series of case studies from around the world, featuring travel by train, bus, cycling and walking. Examples are drawn from Europe, Asia, Australia and the Americas. Cases include the Eurostar train (as an alternative to air travel), walking in the Appalachian Trail (US), the Euro-Velo network of long-distance cycling routes, canoe tours on the Gudena River in Denmark, sea kayaking in British Columbia (Canada) and the $\mathrm{Oz}$ Bus Europe to Australia.

\subsection{Strategic Potential for Economic, Environmental and Social Development}

The study of Manton et al. (2016) [29] analyzes a possible economic impact of greenway investments internationally. From an analysis of an Irish case study, the paper discusses the importance of greenway planning to take full advantage of the benefits for the economy, the environment and society. However, the opposition to direct payment for the use of greenways illustrates the conceptualization of greenway users as a public recreational resource. The article of Tambovceva et al. (2020) [30] provides a practical example of the development of cross-border tourism and its link to achieving sustainable development goals. The authors studied examples of best practice in scientific literature and practice, encouraging the development of cross-border tourism and GWs in Europe and Russia, in order to further adapt it to other continents. Analyzing the environmental, economic, social and institutional factors in the region and their role in sustainable development, the need for institutional regulation that would allow the development of a wider development of GWs is identified. Research results reveal sustainable development dilemmas of positive socioeconomic effects of GWs and negative environmental effects of increased flows of tourists.

\subsection{Appropriate Allocation of Economic Investments}

In the study of Grimaldi et al. (2017) [31], the relationships between regulation and planning tools are compared by a multi-criteria spatial analysis network (analytic network process-ANP). This method, tested on a sample of a city in southern Italy, allows us to optimize the design and location of the investments needed to meet the service criteria, looking at the actual efficiency of the networks. The result of this application is a suitability map that permits us to validate the criteria for defining urban transformations.

From the analysis of the extensive literature reported, the following critical considerations have emerged, regarding the green ways: 
- they bring considerable and multiple benefits to the community, in terms of social and environmental sustainability;

- their implementation is rarely part of public administration policy planning due to lack of funding.

The innovative approach of this study consists in combining the need for sustainable mobility with the need to enhance and recover the identity of inner areas, according to an integrated approach of technical, economic and management practicability.

The study aims at providing operators in the sector with a feasibility tool for the intervention, through a strategy of splitting it into functional lots, according to a hierarchical classification of sub-interventions.

\section{Tools and Methods}

This study aims at elaborating an integrated quali-quantitative method (Figure 1), functional to the design of the technical, economic and managerial feasibility of the intervention, whose objectives are:

- $\quad$ safety and adaptation of the cycle path;

- protection, recovery and enhancement of the natural and man-made environment of the Cilento National Park;

- classification of priorities, through the identification of functional lots.

According to the objectives identified, the methodology is divided into the following phases:

- Phase_1: development of the cycling route

- Phase_2: identification of territorial attractors

- Phase_3: perimeter of the reference territorial area

- Phase_4: definition of thematic tourist itineraries

- Phase_5: design hypothesis of technical and economic feasibility

- Phase_6: definition of intervention priorities

- Phase_7: model validation

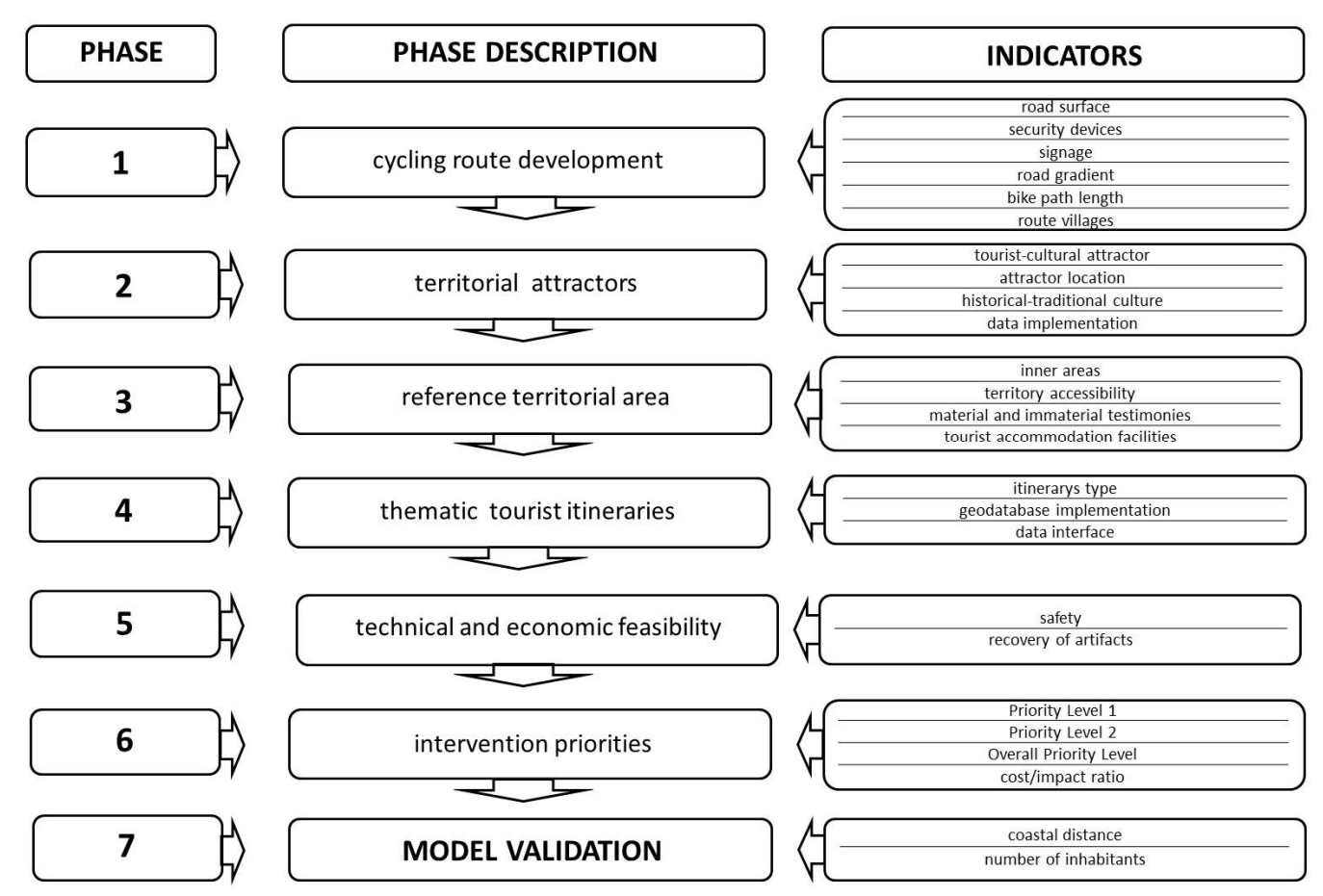

Figure 1. Methodological scheme. 


\subsection{PHASE 1: Development of the Cycling Route}

The selection of cycle routes needs to take into account, as a priority, the safety of the route users. In particular, the indicators used for the methodology are listed here [32]:

- $\quad$ typological and construction characterization of the road surface;

- barriers for the protection of height differences, height jumps and overhangs;

- both vertical and horizontal effective signage, consisting of traditional opaque signs as well as luminous signals;

- $\quad$ roads with undemanding gradients (the gradient of each stage must be suitably marked, as well as any changes along the way);

- possibility of splitting the route into stages (maximum length $=35 \mathrm{~km}$; average length $=$ about $15 \mathrm{~km}$ );

- identification of the map villages.

The reference Italian legislation for the design of cycle paths is Ministerial Decree no. 557/1999 "Regulations containing standards for the definition of the technical characteristics of cycle paths" [32]. The design of the route must preferably be based on existing cycle paths, included in consolidated routes (FIAB-Italian Environment and Bicycle Federation; EuroVelo; etc.), that is, designed using suitable software applications (https://www.naviki.org/it/naviki/informazioni-su-naviki/).

\subsection{PHASE 2: Identification of Territorial Attractors}

This phase requires an in-depth study and analysis of the historical sources of the places concerned, with reference to traditional cultures, as well as material and immaterial testimonies that are distinctive of the places' identity. This information will be acquired through consultation of bibliographic documentation and local written testimonies, to be found in municipal libraries, cultural associations and private archives.

The selection of tourist attractors takes into account the following indicators:

- definition of tourist-cultural attractors, in accordance with the requirements defined by European [33] and national [34] regulations;

- location of the attractor: along the cycle path or in the vicinity (with detours not exceeding $5 \mathrm{~km}$ );

- expression of peculiar and emblematic characteristics of the local historical-traditional culture;

- data systematization in a database, prepared for the development of thematic itineraries (developed in phase 4).

\subsection{PHASE 3: Perimeter of the Reference Territorial Area}

The territorial scope of reference includes all the municipalities that will have to be crossed by the cycling route. In order to enhance and requalify the depopulated and abandoned municipalities, the characteristics of the municipalities to be preferably involved are the following:

- inner areas;

- territories which, due to their geo-morphological configuration, are not easily accessible by traditional roads (i.e., they are not connected by state or national roads);

- municipalities characterized by the presence of peculiar, typical and exclusive local testimonies;

- municipalities with basic facilities, tourist accommodation facilities and which, with this strategy, can be expanded and implemented.

The perimeter of the reference territory must mainly take into account the involvement of the municipalities included in the "National Inner Area Strategies" [3,4].

\subsection{PHASE 4: Identification of the Thematic Tourist Itineraries}

The definition of the tourist itineraries will have to take into account the selection of tourist-cultural attractors, previously identified and selected in phase 2, according to the following features: 
- itineraries type: Worship, Taste, Naturalistic, Sport and Wellness, Archaeology, Water, Historical-Museum, Architectural, Artistic and so forth.;

- use of geodatabases (GPSies, ArchGIS or similar), for the elaboration of thematic maps by the map and iconographic representation of single itineraries;

- data interface with Android/IOS applications, such as: Omio, HYPE, TripCase, Google Trips, TripIt and similar.

\subsection{PHASE 5: Hypothesis of Technical and Economic Feasibility Design}

The preliminary design of the intervention should take into account the achievement of two objectives:

- $\quad$ safety and route adjustment

- recovery and valorization of the works and related artefacts

The safety and route adjustment works shall take into account the regulatory references in force, both at national and local level, as well as the parameters indicated in phase 1.

The works for the recovery and restoration of the annexed structures (dry-stone walls, fences, terraces, etc.), for the discipline and drainage of surface water, shall take into account the Naturalistic Engineering techniques. The technical criteria for the design refer to both national [35] and local regulations [36].

The design, to be elaborated and developed on a BIM platform, must comply with the parameters imposed by current legislation on environmental sustainability, both at a community level (PAN GPP) [37] and at a national one (CAM-Minimum Environmental Criteria in new construction and renovation works) [38].

By means of inspections along the entire route, sample sections will be identified, according to the following criteria:

- morphological characteristics of the route:

- route with coplanar lateral eyelashes;

- route with a coplanar eyelash and a undergone one;

- route type:

- $\quad$ autonomous cycle path;

- $\quad$ mixed cycle path (shared by cars and bicycles);

The design will concern each sample section.

The cost estimate of the intervention will be elaborated on the basis of the regional public works price lists, updated according to the above mentioned environmental directives.

The cost estimate will be made per parametric unit (linear meter of route) of each sample section. The parametric cost will then be extended for the length of each sample stretch, applying the following formula:

$$
\mathrm{Ct}=\Sigma \mathrm{Ct} 1^{*} \mathrm{Lt} 1+\mathrm{C} \mathrm{tn}^{*} \mathrm{Ltn}
$$

where:

$\mathrm{C} t=$ total cost of the intervention

$\mathrm{Ct} 1=$ parametric intervention cost of section " 1. "

Lt1 = length of the stretch "1."

$\mathrm{Ctn}=$ parametric intervention cost of the "-th" section

Ltn = length of the "-th" stretch 
The elaboration of the metric calculation, for the estimation of the intervention costs, will have to be carried out using digital technology, in accordance with the current European Community [39] and national [40] legislation on the integrated management of the construction, maintenance and management process phases.

\subsection{PHASE 6: Definition of Intervention Priorities}

In this phase, the method foresees the definition of an intervention hierarchy. This condition is necessary because, in the case of medium and large works, sometimes the public administration has not got the needed funding to carry out the whole work. Therefore, it is advisable to provide for the work subdivision into functional lots, so as to allow its feasibility over time. In this regard, there are various economic studies aimed at selecting the interventions on the basis of budget availability but through a random, not piloted selection of the interventions to be carried out [41,42].

Therefore, phase 6 consists in the determination of intervention priorities, through the identification of sub-interventions (i.e., functional lots) that can be individually implemented. To this end, phase 6 consists of the following sub-phases:

- $\quad$ 3.6.1 determining of Priority Level 1 (LOP_1)

- $\quad$ 3.6.2 determining of Priority Level 2 (LOP_2)

- $\quad$ 3.6.3 determining of Overall Priority Level (OPL)

- $\quad$ 3.6.4 determining of the cost/impact ratio

\subsubsection{Checking Priority Level 1 (LOP_1)}

The determining of the Priority Level (LOP_1) consists in classifying the individual routes on the basis of the characteristics that determine the users' safety and the territory protection, that is:

- $\quad$ the route length should be, if possible, an average of $15 \mathrm{~km}$;

- number of tourist itineraries (defined in phase 4) intercepted by the route: the first level of priority corresponds to risk mitigation for users, considering the route's most frequented sections;

- inclusion or not, of the route in an inner area (phase 3): this requirement corresponds to the need to requalify and enhance the inner areas, poorly frequented and therefore often subject to abuse acts.

The intensity of the theoretical flow of the route's use is determined through the overlapping of several thematic routes, since the risk, with the same danger, depends on the amount of people exposed (Figure 2) [43].

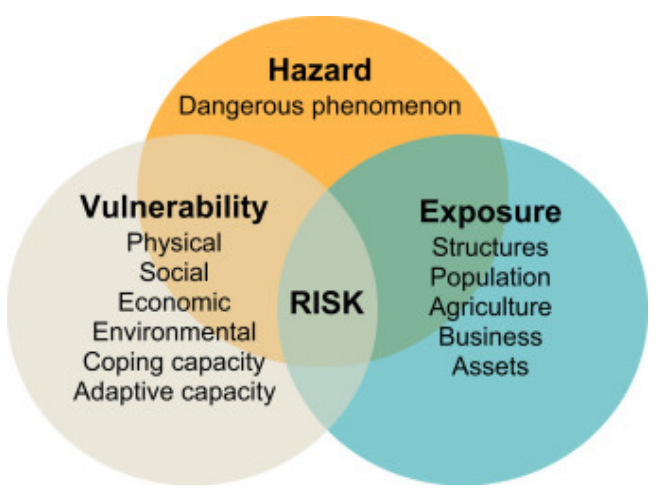

Figure 2. Conceptual framework for disaster risk assessment.

Table 1 shows the calculation scheme of Priority Level n.1. 
Table 1. Priority level 1 checking (LOP_1): classification of route sections, according to the priorities related to the interception of tourist routes and the inclusion of the route in inland areas.

\begin{tabular}{ccccc}
\hline Route Name & Route Length $(\mathbf{k m})$ & Intercepted Itineraries (n) & Inner Areas & Level of Priority (LOP_1) Points \\
\hline $\mathrm{Km}(<15)$ & $(\mathrm{n})$ & YES & $\mathrm{x}$ \\
$\mathrm{Km}(>15)$ & $(\mathrm{n})$ & YES & $(\mathrm{x}-1)$ \\
$\mathrm{Km}(<15)$ & $(\mathrm{n})$ & NO & $(\mathrm{x}-2)$ \\
$\mathrm{Km}(>15)$ & $(\mathrm{n})$ & NO & $(\mathrm{x}-4)$ \\
$\mathrm{Km}(<15)$ & $(\mathrm{n}-1)$ & YES & $(\mathrm{x}-5)$ \\
$\mathrm{Km}(>15)$ & $(\mathrm{n}-1)$ & YES & $(\mathrm{x}-6)$ \\
$\mathrm{Km}(<15)$ & $(\mathrm{n}-1)$ & NO & $(\mathrm{x}-7)$ \\
$\mathrm{Km}(>15)$ & $(\mathrm{n}-1)$ & NO & $(\mathrm{x}-8)$ \\
$\mathrm{Km}(<15)$ & $(\mathrm{n}-2)$ & YES & $(\mathrm{x}-9)$ \\
$\mathrm{Km}(>15)$ & $(\mathrm{n}-2)$ & YES & $(\mathrm{x}-10)$ \\
$\mathrm{Km}(<15)$ & $(\mathrm{n}-2)$ & NO & $(\mathrm{x}-11)$ \\
$\mathrm{Km}(>15)$ & $(\mathrm{n}-2)$ & NO &
\end{tabular}

The attribution of the score, for the LOP_1, will be:

- $\quad$ route length: $\mathrm{km}<15=1 \mathrm{pt} \mathrm{km}>15=0 \mathrm{pt}$

- $\quad$ intercepted itineraries: 1 itinerary $=1 \mathrm{pt}$ " $\mathrm{n}$ " itineraries $=$ " $\mathrm{n}$ " $\mathrm{pt}$

- $\quad$ inner areas: included in the inner area $=1 \mathrm{pt}$ excluded from the inner area $=0 \mathrm{pt}$

\subsubsection{Determining of Priority Level 2 (LOP_2)}

The determining of Priority Level 2 (LOP_2) consists in classifying the individual routes on the basis of criteria concerning logistic, infrastructural, cultural features, that is:

- $\quad$ inclusion of the route in the cycle circuits network on an international scale (e.g., EuroVelo, etc.) - planning of an intermodal transport network, with the possibility of using different types of means of transport, making connections possible on a supra-regional scale, for example with bike-train or bike-boat type modes;

- proximity to historical and cultural sites of recognized world interest (UNESCO sites);

- $\quad$ activation of tourist accommodation facilities (point-office, B\&B, agritourism farms, etc.).

- $\quad$ increase in the number of local tourist guides.

The priority ranking determined by the LOP_2 highlights the preference of the stretches that, due to geographical, infrastructural and socio-cultural characteristics, have the greatest potential for increase, based on the strategic actions identified, thus guaranteeing an optimal return on economic investment.

Indicators 1,2,3 represent strengths of the section considered; indicators 4,5,6 represent critical elements, to be reinforced (Table 2).

Table 2. Determining of priority level 2 (LOP_2): classification of the sections of the route, according to the strategic actions.

\begin{tabular}{|c|c|c|c|c|c|c|c|}
\hline \multirow[b]{2}{*}{$\begin{array}{l}\text { Route } \\
\text { Name }\end{array}$} & 1 & 2 & 3 & 4 & 5 & 6 & \multirow[b]{2}{*}{$\begin{array}{c}\text { Level of } \\
\text { Priority } \\
\text { (LOP_2) } \\
\text { Points }\end{array}$} \\
\hline & $\begin{array}{l}\text { Interception of } \\
\text { International } \\
\text { Cycling Routes }\end{array}$ & $\begin{array}{c}\text { Interception } \\
\text { of Nodes } \\
\text { Intermodal } \\
\text { Transport }\end{array}$ & $\begin{array}{l}\text { Proximity to } \\
\text { UNESCO } \\
\text { Sites }\end{array}$ & $\begin{array}{l}\text { Point-Office } \\
\text { Equipment }\end{array}$ & $\begin{array}{l}\text { Presence of } \\
\text { Local Tourist } \\
\text { Guides } \\
\text { Association }\end{array}$ & $\begin{array}{c}\text { Tourist } \\
\text { Accommodation } \\
\text { Facilities }\end{array}$ & \\
\hline & YES & YES & YES & $\mathrm{NO}$ & $\mathrm{NO}$ & $\mathrm{NO}$ & 6 \\
\hline & $\mathrm{NO}$ & $\mathrm{NO}$ & $\mathrm{NO}$ & YES & YES & YES & 0 \\
\hline
\end{tabular}

This will be the attribution of the score for the LOP_2:

$1-2-3(\mathrm{YES})=1 \mathrm{pt} 1-2-3(\mathrm{NO})=0 \mathrm{pt}$

$4-5-6(\mathrm{YES})=0 \mathrm{pt} 4-5-6(\mathrm{NO})=1 \mathrm{pt}$ 


\subsubsection{Determining of the Overall Priority Level (OPL)}

After defining the scores related to the two Priority Levels (LOP_1 and LOP_2), the Overall Priority Level (OPL) (Table 3) is defined as follows, by summing the scores obtained, from each trait, in LOP_1 and LOP_2.

Table 3. Overall Priority Level checking (OPL).

\begin{tabular}{cc}
\hline Route Name & Overall Priority Level (OPL) \\
\hline $\mathrm{x}$ \\
$(\mathrm{x}-1)$ \\
$(\mathrm{x}-2)$ \\
$(\mathrm{x}-3)$ \\
\hline
\end{tabular}

\subsubsection{Determining of the Cost/Impact Ratio}

The phase involves estimating the intervention costs of the individual sections: Table 4 classifies the individual sections by assigning a score for 'bands' of cost (from the lowest to the highest cost of intervention). Then, the convenience ratio (Table 5) of each section is determined, that is, the ratio between the cost of the intervention and the potential impact, in terms of tourist enhancement of the site, connected to the use of the section.

Table 4. Estimate of intervention costs for each route.

\begin{tabular}{cc}
\hline Route Name & Cost of Intervention \\
\hline$€<1 \mathrm{mln}$ \\
$1 \mathrm{mln}<€<2 \mathrm{mln}$ \\
$2 \mathrm{mln}<€<3 \mathrm{mln}$ \\
$3 \mathrm{mln}<€<4 \mathrm{mln}$ \\
$€>4 \mathrm{mln}$ \\
\hline
\end{tabular}

Table 5. Evaluation of intervention priorities according to the optimization of the cost/impact ratio of the intervention.

\begin{tabular}{cc}
\hline Route Name & Cost/Impact Ratio \\
\hline $\mathrm{x}$ \\
$(\mathrm{x}-1)$ \\
$(\mathrm{x}-2)$ \\
$(\mathrm{x}-3)$ \\
$(\mathrm{x}-4)$ \\
\hline
\end{tabular}

The attribution of the economic score will be:

$€<1 \mathrm{mln}=5 \mathrm{pt}$

$\mathrm{mln}<€<2 \mathrm{mln}=4 \mathrm{pt}$

$\mathrm{mln}<€<3 \mathrm{mln}=3 \mathrm{pt}$

$\mathrm{mln}<€<4 \mathrm{mln}=2 \mathrm{pt}$

$€>4 \mathrm{mln}=1 \mathrm{pt}$

\subsection{PHASE 7: Model Validation}

The methodology foresees the model validation, in order to verify if the results obtained correspond to the real situation. In other words, whether the 'priority' countries, following the elaboration of the model, are really the ones with the greatest criticality, in terms of depopulation and distance from the most inhabited tourist centers (Table 6). For this validation, therefore, the indicators to be taken as a reference are: 
- coastal strip distance

- inhabitants number

- distance from the coastal strip

Table 6. Model validation.

\begin{tabular}{cccc}
\hline Route Name & Cost/Impact Ratio & Coastal Strip Distance & Inhabitants \\
\hline $\mathrm{x}$ & $\mathrm{x}$ & $\mathrm{x}$ \\
$(\mathrm{x}-1)$ & $(\mathrm{x}+1)$ & $(\mathrm{x}-1)$ \\
$(\mathrm{x}-2)$ & $(\mathrm{x}+2)$ & $(\mathrm{x}-2)$ \\
\hline
\end{tabular}

For the development of this indicator, the closest coastal countries with the highest number of inhabitants must be taken as a reference.

The points to be awarded are: $(0-5 \mathrm{~km}=1 \mathrm{pt}) ;(6-10 \mathrm{~km})=2$ pts; $(11-15 \mathrm{~km}=3$ pts $)$; (16-20 km = 4 pts); (21-25 km = 5 pts); (26-30 km = 6 pts); (31-35 km = 7 pts); (36-40 km = 8 pts); $(41-45 \mathrm{~km}=9$ pts); (46-50 km = 10 pts); (51-55 km = 11 pts); (56-60 km = 12 pts); $(61-65 \mathrm{~km}=13$ pts).

- number of inhabitants

The points to be awarded are: $(0-1000 \mathrm{in} .=13 \mathrm{pts}) ;(1001-2000 \mathrm{in} .=12 \mathrm{pts}) ;(2001-3000 \mathrm{in} .=11 \mathrm{pts})$; $(3001-4000$ in. $=10$ pts $) ;(4001-5000$ in. $=9$ pts $) ;(5001-6000$ in. $=8$ pts $) ;(6001-7000$ in. $=7$ pts $)$; (7001-8000 in. $=6$ pts); (8001-9000 in. $=5$ pts); $(9001-10,000$ in. $=4$ pts $) ;(10,001-11,000$ in. $=3$ pts ; $(11,001-12,000$ in. $=2$ pts $) ;(12,001-13,000$ in. $=1$ pt $)$.

\section{Application of the Method to the Case Study}

\subsection{Description of Case Study}

Inner Cilento represents geographically an area located between two zones with a well-defined and consolidated identity: the coastal Cilento and the Cilento and Vallo di Diano National Park. The coastal Cilento is an area characterized by a particular tourist and receptive value, as well as by a recognized naturalistic-environmental and historical-archaeological value: the tourist destinations of Sapri, Marina di Camerota, Palinuro, Elea-Velia, represent a fundamental economic induction for the development of these territories. The Cilento and Vallo di Diano National Park is characterized by an exceptional naturalistic and environmental value, certified by prestigious awards: in 1998, the site was inscribed in the UNESCO World Heritage List; in 2007, it obtained the UNESCO MAB (Man and Biosphere) qualification. Moreover, it is included in the UNESCO Global Geo-parks Network list, as well as the only community, in Italy, of the UNESCO Intangible Heritage, representative of the "Mediterranean Diet." The progressive depopulation and ageing of the surviving community threaten this territorial heritage, leaving it to degradation and abandonment.

The starting point is the reconstruction of economic networks that have governed these territories for millennia. So, within this paradigm, as a priority, investments will be strategically concentrated on the following measures [44]: Mediterranean diet, wood, traditional jobs, health and well-being, new inhabitants, travelling in inner Cilento, accessibility demand.

The development of Cilento has always been linked to the catalyzing action carried out by the coastal strip, neglecting the inner areas. In recent years, however, the debate has been focused on the attempt to deseasonalize tourism [45]. Cycling attraction planning would allow not only to expand the tourist offer to other categories of users but also to catalyze coastal tourists towards the inner Cilento and Vallo di Diano, thus ensuring a constant flow of presences. Among the opportunities of the strategic choice should not be overlooked the fallout resulting from careful maintenance, conservation and protection of involved areas, through the recovery of the minor path, mule tracks and trazzère, as well as all those infrastructures connected to it such as dry-stone walls, millstones, riparian strips and so 
forth. In addition, the frequentation of such places guarantees vigilance and protection measures of the places themselves, presumably discouraging the continuous and perpetrated environmental abuses committed to the detriment of these territories.

\subsection{Phase 1: Development of the Cycling Route}

The case study is a cycling route about 600 kilometers long, with a total travel time of about 28 days. The Cilento Association "La Via Silente" [46] has traced a cycle route, unique of its kind, which runs entirely within a protected area, one of the largest national parks in Italy, a biosphere reserve and UNESCO World Heritage Site since 1998, as well as a Geopark. The Association's objectives are to enhance the territory value and to deseasonalize tourism. Via Silente (The Silent Way) owes its name to the sound of the places it crosses, where silence sets in overwhelmingly, almost completely neutralizing the noise of human activities.

The ring-route (Figure 3), divided into 15 stages, winds for $200 \mathrm{~km}$ along the coast and for the remaining $400 \mathrm{~km}$ in Cilento inner areas, Valle di Diano and Alburni National Park, with the highest peak at $1898 \mathrm{~m}$ above sea level, Mount Cervati, crossing the river Calore, the caves of Castelcivita and Pertosa, woods, valleys and rural villages. The stages have a different level of difficulty (marked at the beginning of the stage): easy, medium, difficult, challenging. Before the departure, from Castelnuovo Cilento village, all cyclists who want to face the Silent Way can pick up the "Silentina," a travel document that allows them to use board and lodging, at agreed prices, along the whole itinerary. It takes about four weeks to complete the route but you can also choose to ride only a stretch or just some or ask for an assisted tour, a service offered by the local association "La Via Silente." The World Cycling Day, held on 3 June 2020, celebrated the "Via Silente" among the 5 most beautiful cycle paths in Italy, together with the Ciclopista del Garda (Lake Garda), the Riviera dei Fiori cycle path (Liguria), L'Eroica (Tuscany), the "Rossana Maiorca" cycle path (Sicily) [47].

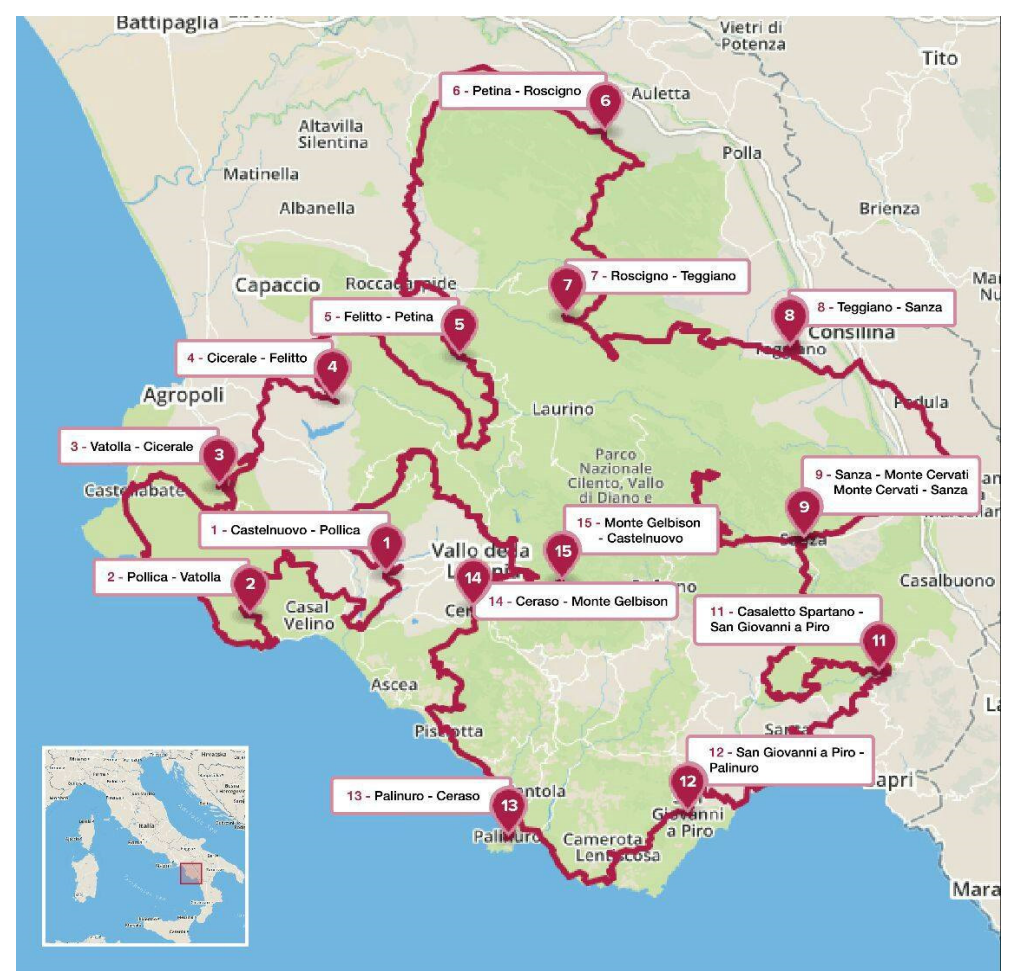

Figure 3. Mapping of the 15 stages of the Silent Way. 


\subsection{Phase 2: Identification of Territorial Attractors}

Cilento is an area rich in cultural, historical-artistic, naturalistic, environmental, ethno-anthropological attractions and even more. It extends for more than 1800 square kilometers, is characterized by an extreme morphological heterogeneity, with extensive plains, mountain ranges, peaks even two thousand meters high, as well as a vast variety of biodiversity, flora and fauna, grassy plains and impenetrable woods, karst swallows, lakes and rivers. In Felitto, the Calore river digs deep gorges, with walls up to ten meters high, drawing an uncontaminated landscape. The Gole del Calore association offers canoe trips, guided trekking and canyoning routes to descend into the inaccessible karst gorges of the river. The small village of Felitto is perched on the cliff overlooking the river: it still preserves portions of the surrounding walls dating back to the year 1000 and some of the 13 watchtowers that defended the town, narrow around the ramparts of the Church of Santa Maria dell'Annunziata. Stio, a small town with 800 inhabitants, is another hidden treasure: stone houses with carved portals and flowered balconies and the church of Holy Saints Peter and Paul. The stretch leading from Stio to Felitto is a bike ride of about $20 \mathrm{~km}$, bordering turkey oak and beech woods, with wide views over the river Alento valley. A must-stop is "the old Roscigno," known as the ghost town, where everything seems to have stopped at the beginning of the twentieth century, when its inhabitants were invited by the Civil Engineers to leave their homes due to the ground instability. The square, with a large washhouse fountain, the mother church, the houses built in stone bound with lime and sand, the stables and the cellars bear witness to the typical rural architecture of the millenary period. The Via Silente is above all a journey of encounters, of stories, of faces that remain impressed in the memory. The Sella del Corticato saddle, a thousand meters above sea level, connects the Sammaro valley with the Vallo di Diano, another notable area in the inner area: in spring the asphalt bends draw a grey ribbon between the green and yellow pastures of broom. You ride in the middle of a majestic landscape: on one side the bare and rocky walls of Cocuzzo delle Puglie and, on the other, Monte Motola's one, covered with silver fir woods, the only evidence still existing in Cilento. Going down towards the valley, you cross the Teggiano village, built around Macchiaroli baronial castle-Antichi Feudi hotel is what remains from the historic center, obtained from a historical palace, with a view on the valley. In Teggiano, the Cilento Outdoor Association offers guided hikes along the mountain paths, to discover Alburni Mountains, the so-called Southern Dolomites, which extend north of the Park, rich in karst caves and thick chestnut groves and characterized by relevant peaks: Mount Gelbison, sacred for the Cilento people; Cervati, the highest peak in Campania with its $1899 \mathrm{~m}$, with wide beech woods. Its peak can be got by bike: this is the fifteenth stage of the Via Silente, the one with the highest difficulty quotient. There is also another way to experience Cervati, on foot, starting from the top, with an hour trekking walk. From Monte Cervati the river Bussento rises and, after a few kilometers, sinks into a large swallow hole to re-emerge, near Morigerati town, from an imposing cave, between high and steep canyons. Since 1985, the area where the resurgence of Bussento occurs has been managed by the WWF (World Wildlife Fund) which accompanies visitors along the paths of the oasis, passing through small waterfalls and gorges, up to an old 17th century mill. Walking along an old mule track, for about one kilometer, you get Morigerati, the Paese Ambiente, which is also one of the thousand Italian villages listed by the Ministry of Cultural Heritage for the Year of Villages. Its inhabitants, just over 700, open their homes to visitors with a formula of widespread hospitality. The bike journey goes on with a stop at Casaletto Spartano and the Cascata dei Capelli di Venere, other naturalistic attractions and then heads towards the sea of Policastro Gulf, rejoining the Tyrrhenian Sea. Here the Via Silente also touches the coastal villages of Pioppi, Palinuro, Pisciotta, Acciaroli and Pollica.

\subsection{Phase 3: Perimeter of the Reference Territorial Scope}

In order to implement the methodological proposal, a large scale territorial area, hypothetically involved in the valorization strategy, was perimeterized. 
The perimeter of this vast area took into account criteria on the basis of which 70 municipal territories were identified (Figure 4).

\begin{tabular}{|c|l|}
\hline & $\begin{array}{l}\text { Area including the municipalities crossed by } \\
\text { the Silent Way route, some of which belong to } \\
\text { the inner areas (see table below) }\end{array}$ \\
\hline & $\begin{array}{l}\text { Municipalities belonging to the Cilento Inner } \\
\text { Area, not crossed by the Silent Way route }\end{array}$ \\
\hline $\begin{array}{l}\text { Municipalities belonging to the Vallo of Diano } \\
\text { area, not crossed by the Silent Way route }\end{array}$ \\
\hline
\end{tabular}

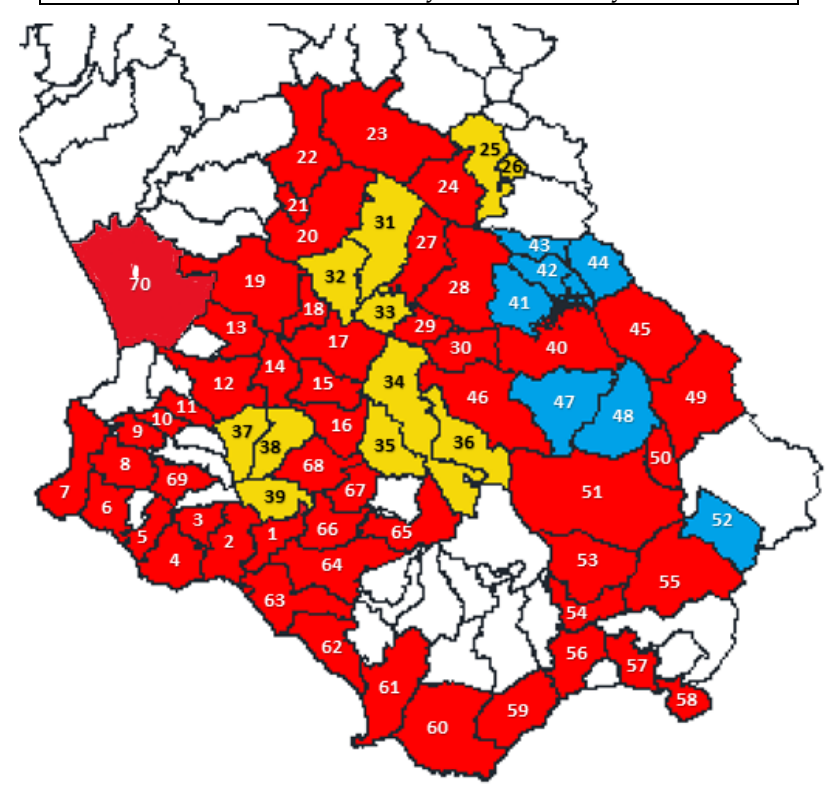

Figure 4. Mapping of the territorial area under study.

The criteria for the inclusion of municipalities are:

- Municipal territories crossed by the Via Silente route, some of which belong to the inner Areas;

- municipal territories belonging to the Inner Cilento area, not crossed by the Via Silente route;

- municipal territories belonging to the Vallo di Diano area, not crossed by the Via Silente route.

\subsection{Phase 4: Definition of Thematic Tourist Itineraries}

The analysis of the real and potential tourist offer required a search for news and testimonies, both documentary and in the field. The work has been carried out at the level of each municipality and then by systematizing the whole study area. The different tangible and intangible resources of the territory, as well as the main properties that characterize them, were identified and entered in the database [44]. All tangible entities have been geo-referenced according to their actual location, while the intangible ones, referring to intangible assets, have been geolocalized in the pivot of the reference municipality or prevalence area. For the potential tourist demand, different segments were considered (seniors, young people, families) for which it was possible to identify an offer, in terms of tourist itinerary, according to the different periods of the year and different themes: nature, culture, food and wine and so forth. In order to deseasonalize the tourist offer, weight has also been given to each resource in terms of "temporal attraction," that is, fields have been defined that indicate the periods of the year in which each resource is more or less attractive. Usually the major tourist flows are linked to the summer period but it is assumed that many resources are attractive for much longer periods and that the potential of each attraction must be exploited as long as possible. However, in several cases there are objective limitations to the tourist fruition during the winter months, especially with regard 
to environmental assets, due to bad weather and hydrogeological conditions. Therefore, each resource has been assigned a weight according to the theme and the time of year. The selection led to the identification of routes that contain most of peculiar and identity emergencies of Cilento's civilization, culture and history. These are the itineraries developed:

(A) Christian Worship Itinerary: a thousand-year-old land could only have a close link with the religion that in Cilento counts the most faithful, the Christian faith. The religious events that take place in Cilento are numerous and very much felt by the local population and, as well as the events, there are many worship places where you can go for a pilgrimage. The itinerary par excellence linked to the Christian faith the "7 Sisters" one: Seven Sanctuaries devoted to the Madonna. In this area the sanctuaries are located on hills that close in a circle towards the sea, almost in a magical protection of the area.

(B) Sport and Adventure Itinerary: this itinerary allows you to cross the highest peaks of Cilento, enjoying unique naturalistic views, passing through the hilly landscape of olive groves and vineyards, until you get the sea and then take advantage of boat trips along the characteristic Cilento coast. The most fascinating experiences are "Cilento in Volo," in Trentinara, scuba diving, at the Marina di Casal Velino, Trekking on Gelbison Mount (Novi Velia), Windsurfing course in Pollica, canoe trips, among the Gole del Calore in the municipality of Felitto.

(C) Archaeology Itinerary: Cilento territory hosts archaeological evidences of considerable importance, with the discovery of numerous finds from different periods. The first human settlements date back to the Palaeolithic Age and until the Copper Age the inhabitants of these places left traces of their passage in the coastal caves. Around the VIII century B.C. Greek colonizers of Magna Graecia left their marks on this territory with the foundation of Poseidonia and the Mouths of Minor Asia by founding Elea-Velia.

(D) Taste Itinerary: from the gastronomic point of view, Cilento is a land rich in a variety of excellent products, among which DOP oil and fine vines (such as D.O.C. Castel San Lorenzo and D.O.C. Cilento), products that have made Cilento the cradle of the Mediterranean Diet, recognized in 2010 as an intangible cultural heritage of humanity. Among the excellence products are Pertosa white artichokes, Controne D.O.C. beans, Roccadaspide I.G.P. chestnuts, Paestum D.O.P. buffalo mozzarella, Cicerale chickpea, Prignano Cilento D.O.P. white figs, Vatolla onions, Menaica of Marina di Pisciotta anchovies.

(E) Water Itinerary: inner Cilento is a luxuriant, fertile land, rich in watercourses which, in history, have represented the main roads for raw materials and food movements. Watercourses, originating from the bowels of the Cilento highlands, flow along inaccessible paths, valleys, gorges, swallow holes and resurgences, giving rise to wonderful and characteristic natural sceneries, typical of these natural places. Among the most suggestive watercourses are the springs of the Sammaro torrent, in the territory of the municipality of Sacco, the Gole del Calore in the municipality of Felitto, the Alento river, Dam and Oasis, in Prignano Cilento, the Mingardo river, in the municipality of San Severino, the Bussento river, WWF Oasis, in Morigerati (Figure 5).

(F) Historical-Museum Itinerary: the Historical-Museum Itinerary connects, along the cycling route, some of the most important museums of Cilento, offering the opportunity to enjoy a rich and interesting historical-artistic heritage. The emergencies are the Charterhouse of Padula, UNESCO World Heritage since 1998, the Museum of Medical Herbs of Teggiano, the Paleontological Museum of Magliano Vetere, the National Archaeological Museum of Capaccio Paestum.

(G) Naturalistic Itinerary: the Naturalistic Itinerary is a route designed to connect, with a single route, some of the emergencies of the National Park of Cilento, sites of high naturalistic and environmental value. Among the main emergencies, the Caves of the Angel, Pertosa-Auletta, the Caves of Castelcivita, Punta Licosa, the Caves of Capo Palinuro. 


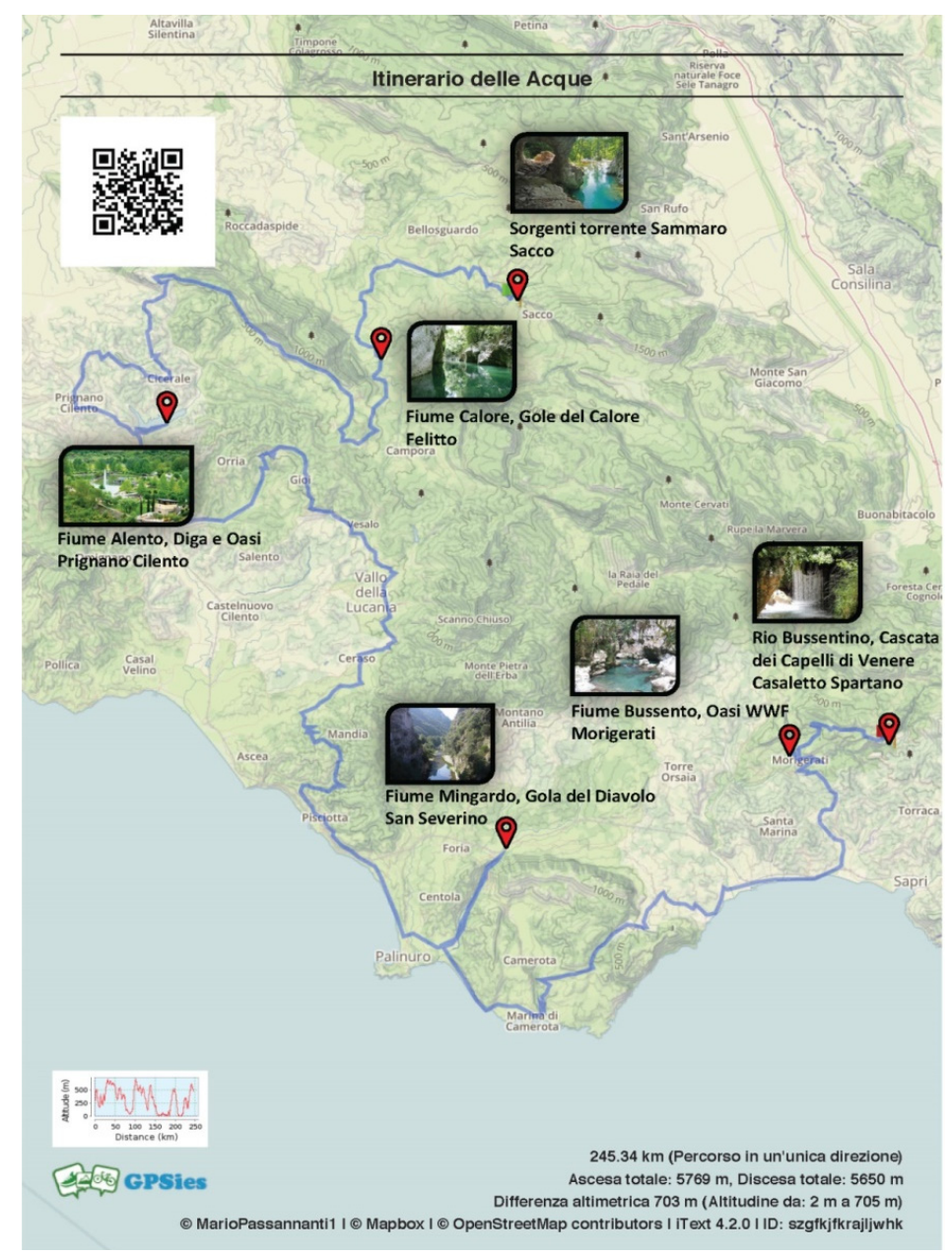

Figure 5. Thematic route: Water Itinerary (elaborated with software GPSies).

\subsection{Phase 5: Technical and Economic Feasibility Design Hypothesis}

The design of the intervention took into account the achievement of two objectives:

- $\quad$ safety and route adjustment

- recovery and valorization of the works and related artefacts

Safety and route adjustment works took into account current national and local regulatory references [31]. The works of recovery and restoration of the annexed structures (dry-stone walls, fences, terraces, etc.), of discipline and drainage of surface water, have to take into account the techniques of Naturalistic Engineering [34,35].

The inspections along the route made possible to select two types of route (Figures 6 and 7), having the following characteristics:

- $\quad$ typology 1: route with coplanar, promiscuous side lines;

- $\quad$ route with one coplanar edge and a subject, promiscuous one. 


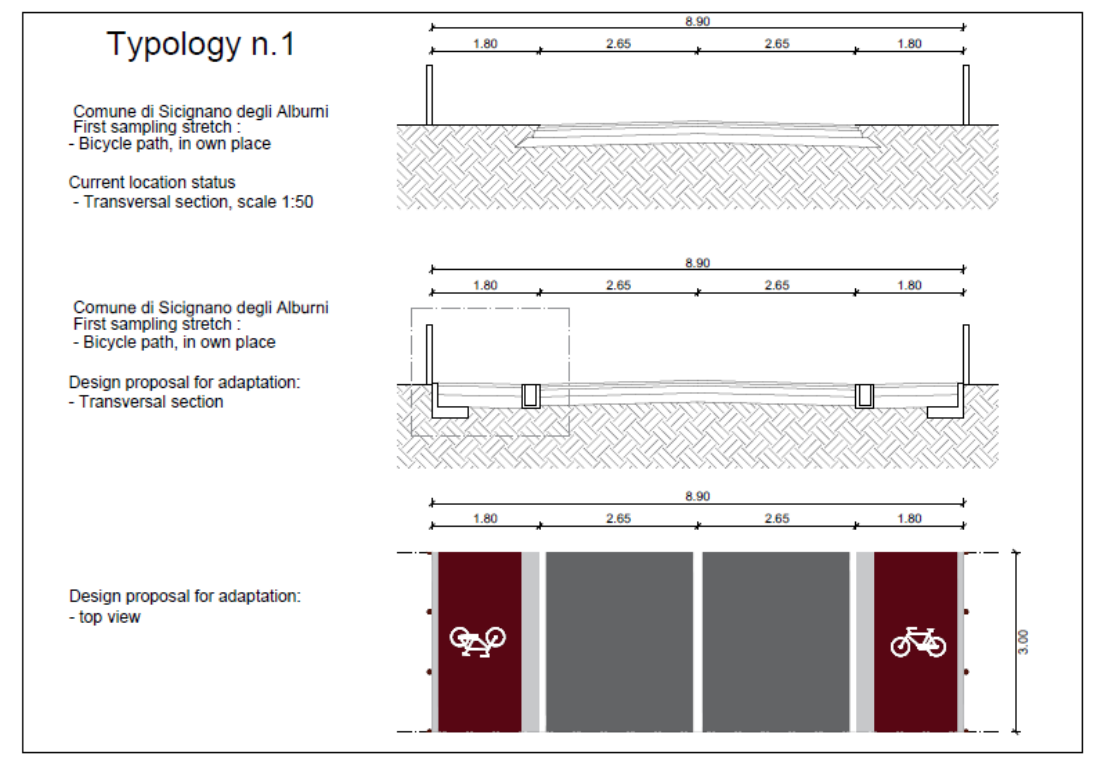

Figure 6. Design proposal for the type of route n.1.

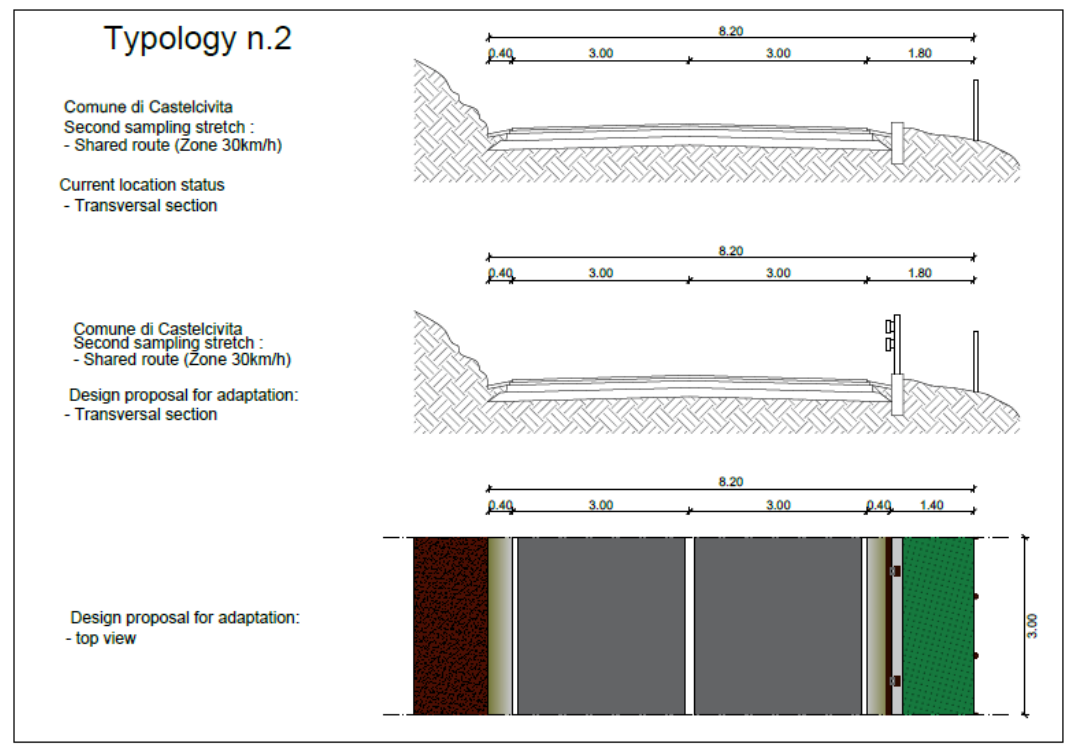

Figure 7. Design proposal for the type of route n.2.

The intervention costs estimate was drawn up on the basis of the Regione Campania's public works tariff. The relevant tariff has been updated, in 2020, to the requirements of the Minimum Environmental Criteria [37].

Data processing was carried out in digital mode, in compliance with current Italian regulations [48], using PRIMUS software (ACCAsoftware).

In summary, results are:

Type 1 - parametric cost of intervention $=€ 94.82 / \mathrm{mL}$

Type 2 -parametric cost of intervention $=€ 80.13 / \mathrm{mL}$

A $40 \%$ surcharge has been applied to the estimated cost of carrying out the works, relating to external costs: technical costs (design, supervision of the works, safety coordination, testing, etc.), safety costs; contingencies and so forth.

Therefore, the average cost, per linear meter, of an upgrade for a cycle path along the Via Silente in the National Park of Cilento, Vallo di Diano and Monti Alburni is of: 
Type $1=€ 94.82 * 40 \%=€ 132.74 / \mathrm{mL}$

Type $2=€ 80.13 * 40 \%=€ 112.18 / \mathrm{mL}$

By extending the unit cost for the length of the respective paths, we obtain a parametric cost, per linear meter, equal to $€ 122.46 / \mathrm{mL}$, from which we can deduce the total cost of the intervention:

$$
\mathrm{Ct}=\mathrm{Cmu}{ }^{*} \mathrm{Lt},
$$

where:

$\mathrm{Ct}$ is the total cost of the intervention $(€)$

$\mathrm{Cmu}$ is the average unit cost (expressed in linear meters)

$\mathrm{Lt}$ is the total length of the route (expressed in linear meters)

that is,

$$
\mathrm{Ct}=€ 122.46 / \mathrm{mL} \times 600.000 \mathrm{~mL}=€ 73,476.000 .
$$

\subsection{Phase 6: Definition of Intervention Priorities}

\subsubsection{Determining of Priority Level 1 (LOP_1)}

Table 7 shows the elaboration of the model for the definition of Priority Level 1 (LOP_1). The parameters taken as reference for the determination of this priority level are:

- path length

- $\quad$ number of tourist itineraries intercepted (Figure 8)

- $\quad$ inclusion or not, in Inner Areas

Table 7. Determining of Priority Level 1: classification of the route sections, according to the priorities related to the interception of tourist itineraries and the inclusion of the route in the inner areas

\begin{tabular}{|c|c|c|c|c|}
\hline Route Name & Length & $\begin{array}{c}\text { Intercepted } \\
\text { Itineraries (n) }\end{array}$ & $\begin{array}{l}\text { Inner } \\
\text { Areas }\end{array}$ & $\begin{array}{c}\text { Level of Priority (LOP_1) } \\
\text { Points }\end{array}$ \\
\hline Vallo della Lucania-Gioi & $14.4 \mathrm{~km}$ & 4 & YES & 6 \\
\hline Vatolla-Prignano Cilento & $15.3 \mathrm{~km}$ & 4 & YES & 6 \\
\hline Prignano Cilento-Cicerale & $10.6 \mathrm{~km}$ & 4 & YES & 6 \\
\hline Trentinara-Stio & $20.1 \mathrm{~km}$ & 4 & YES & 5 \\
\hline Marina di Camerota-Palinuro & $12.9 \mathrm{~km}$ & 4 & $\mathrm{NO}$ & 5 \\
\hline Palinuro-Pisciotta & $11.9 \mathrm{~km}$ & 4 & NO & 5 \\
\hline Ceraso_-Vallo della Lucania & $6.6 \mathrm{~km}$ & 3 & YES & 5 \\
\hline Stio-Felitto & $14.2 \mathrm{~km}$ & 3 & YES & 5 \\
\hline Cicerale-Trentinara & $13.3 \mathrm{~km}$ & 3 & YES & 5 \\
\hline Gioi-Omignano & $16.2 \mathrm{~km}$ & 3 & YES & 4 \\
\hline Roccadaspide-Castelcivita & $14.4 \mathrm{~km}$ & 2 & YES & 4 \\
\hline Sicignano degli Alburni-Petina & $8.0 \mathrm{~km}$ & 2 & YES & 4 \\
\hline Pisciotta-Ceraso & $23.9 \mathrm{~km}$ & 3 & $\mathrm{NO}$ & 3 \\
\hline Castellabate-Vatolla & $16.6 \mathrm{~km}$ & 3 & NO & 3 \\
\hline Acciaroli-Castellabate & $21.5 \mathrm{~km}$ & 3 & $\mathrm{NO}$ & 3 \\
\hline Felitto-Roccadaspide & $16.5 \mathrm{~km}$ & 2 & YES & 3 \\
\hline Castelcivita-Sicignano degli Alburni & $18.5 \mathrm{~km}$ & 2 & YES & 3 \\
\hline Morigerati-Casaletto Spartano & $11.9 \mathrm{~km}$ & 2 & $\mathrm{NO}$ & 3 \\
\hline Casaletto Spartano-San Giovanni a Piro & $37.2 \mathrm{~km}$ & 2 & $\mathrm{NO}$ & 2 \\
\hline San Giovanni a Piro-Marina di Camerota & $15.3 \mathrm{~km}$ & 2 & $\mathrm{NO}$ & 2 \\
\hline Teggiano-Padula & $17.3 \mathrm{~km}$ & 1 & YES & 2 \\
\hline Sanza-Morigerati & $26.6 \mathrm{~km}$ & 1 & YES & 2 \\
\hline Castelnuovo Cilento-Marina di C. Velino & $11.2 \mathrm{~km}$ & 1 & $\mathrm{NO}$ & 2 \\
\hline
\end{tabular}
(application to the case study). 


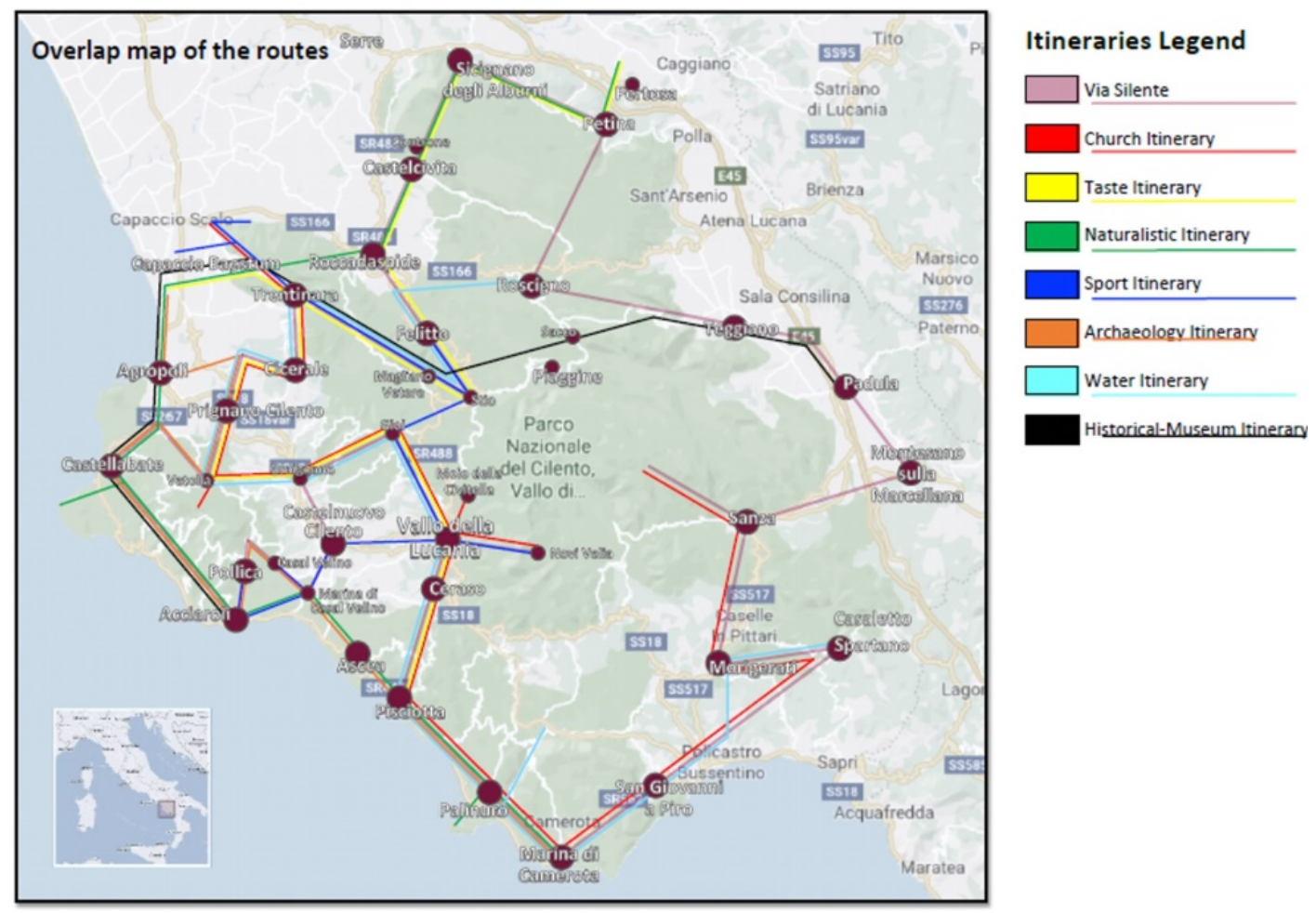

Figure 8. Mapping of the overlapping of the thematic paths.

4.7.2. Determining of Priority Level 2 (LOP_2)

Table 8 shows the application of the model for the definition of Priority Level 2 (LOP_2). The parameters taken as reference for the determination of this priority level are:

- interception of international cycling routes

- interception of nodes intermodal transport

- proximity to UNESCO sites

- point-office

- presence of local tourist guides association

- tourist-accommodation facilities 
Table 8. Determining of Priority Level 2: classification of route sections, according to strategic actions (application to the case study).

\begin{tabular}{|c|c|c|c|c|c|c|c|}
\hline & 1 & 2 & 3 & 4 & 5 & 6 & \\
\hline Route Name & $\begin{array}{l}\text { Interception of } \\
\text { International } \\
\text { Cycling Routes }\end{array}$ & $\begin{array}{c}\text { Interception of } \\
\text { Nodes Intermodal } \\
\text { Transport }\end{array}$ & $\begin{array}{l}\text { Proximity to } \\
\text { UNESCO } \\
\text { Sites }\end{array}$ & $\begin{array}{l}\text { Point Office } \\
\text { Equipment }\end{array}$ & $\begin{array}{l}\text { Presence of Local } \\
\text { Tourist Guides } \\
\text { Association }\end{array}$ & $\begin{array}{c}\text { Tourist } \\
\text { Accommodation } \\
\text { Facilities }\end{array}$ & $\begin{array}{l}\text { Level of Priority } \\
\text { (LOP_2) Points }\end{array}$ \\
\hline Prignano Cilento-Cicerale & YES & YES & YES & NO & NO & NO & 6 \\
\hline Gioi-Omignano & YES & NO & YES & NO & NO & NO & 5 \\
\hline Cicerale-Trentinara & NO & NO & YES & NO & NO & NO & 4 \\
\hline Morigerati-Casaletto Spartano & NO & NO & YES & NO & NO & NO & 4 \\
\hline Casaletto Spartano-San Giovanni a Piro & NO & NO & YES & NO & NO & NO & 4 \\
\hline Sanza-Morigerati & NO & NO & YES & NO & NO & NO & 4 \\
\hline Vallo della Lucania-Gioi & YES & YES & YES & YES & YES & YES & 3 \\
\hline Trentinara-Stio & NO & NO & YES & NO & NO & YES & 3 \\
\hline Vatolla-Prignano Cilento & NO & NO & NO & NO & NO & NO & 3 \\
\hline Ceraso_-Vallo della Lucania & YES & YES & YES & YES & YES & YES & 3 \\
\hline Stio-Felitto & NO & NO & YES & NO & NO & YES & 3 \\
\hline Felitto-Roccadaspide & NO & NO & YES & NO & NO & YES & 3 \\
\hline Roccadaspide-Castelcivita & NO & NO & YES & NO & NO & YES & 3 \\
\hline Marina di Camerota-Palinuro & NO & YES & YES & YES & YES & YES & 2 \\
\hline Palinuro-Pisciotta & NO & YES & YES & YES & YES & YES & 2 \\
\hline Pisciotta—Ceraso & YES & $\mathrm{NO}$ & YES & YES & YES & YES & 2 \\
\hline Acciaroli-Castellabate & NO & YES & YES & YES & YES & YES & 2 \\
\hline Castelcivita—Sicignano degli Alburni & NO & YES & YES & YES & YES & YES & 2 \\
\hline Sicignano degli Alburni-Petina & NO & YES & YES & YES & YES & YES & 2 \\
\hline San Giovanni a Piro-Marina di Camerota & NO & YES & YES & YES & YES & YES & 2 \\
\hline Teggiano-Padula & NO & YES & YES & YES & YES & YES & 2 \\
\hline Castelnuovo Cilento-Marina di C. Velino & NO & YES & YES & YES & YES & YES & 2 \\
\hline Castellabate-Vatolla & NO & YES & NO & YES & YES & YES & 1 \\
\hline
\end{tabular}




\subsubsection{Determining of Overall Priority Level Verification (OPL)}

Table 9 determines the Overall Priority Level (OPL), through the sum of the scores acquired, for each route, in Priority Levels n.1 and n.2.

Table 9. Determining of Overall Priority Level (case study application).

\begin{tabular}{cc}
\hline Route Name & Overall Priority Level (OPL) \\
\hline Prignano Cilento-Cicerale & 12 \\
Cicerale-Trentinara & 9 \\
Gioi-Omignano & 9 \\
Vallo della Lucania-Gioi & 9 \\
Vatolla-Prignano Cilento & 9 \\
Ceraso-Vallo della Lucania & 8 \\
Stio-Felitto & 8 \\
Trentinara-Stio & 8 \\
Marina di Camerota-Palinuro & 7 \\
Morigerati-Casaletto Spartano & 7 \\
Palinuro-Pisciotta & 7 \\
Roccadaspide-Castelcivita & 7 \\
Casaletto Spartano-San Giovanni a Piro & 6 \\
Felitto-Roccadaspide & 6 \\
Sanza-Morigerati & 6 \\
Sicignano degli Alburni-Petina & 6 \\
Acciaroli-Castellabate & 5 \\
Castelcivita-Sicignano degli Alburni & 5 \\
Pisciotta-Ceraso & 5 \\
Castellabate-Vatolla & 4 \\
Castelnuovo Cilento-Marina di C. Velino & 4 \\
San Giovanni a Piro-Marina di Camerota & 4 \\
Teggiano-Padula & 4 \\
\hline
\end{tabular}

\subsubsection{Determining of Cost/Impact Ratio (OPL)}

Table 10 shows the intervention cost, quantified for each section of the cycle route, according to the parametric amounts calculated per functional unit and type of route. Based on the cost of intervention, the individual routes have been sorted in an increasing order.

Table 10. Intervention costs estimate per each path (application to the case study).

\begin{tabular}{cc}
\hline Route Name & Cost of Intervention \\
\hline Sicignano degli Alburni-Petina & $€ 979,680$ \\
Prignano Cilento-Cicerale & $€ 1,298,076$ \\
Castelnuovo Cilento-Marina di C. Velino & $€ 1,371,552$ \\
Morigerati-Casaletto Spartano & $€ 1,457,274$ \\
Palinuro-Pisciotta & $€ 1,457,274$ \\
Marina di Camerota-Palinuro & $€ 1579734$ \\
Cicerale-Trentinara & $€ 1,628,718$ \\
Stio-Felitto & $€ 1,738,932$ \\
Vallo della Lucania-Gioi & $€ 1,763,424$ \\
Roccadaspide-Castelcivita & $€ 1,763,424$ \\
Vatolla-Prignano Cilento & $€ 1,873,638$ \\
San Giovanni a Piro-Marina di Camerota & $€ 1,873,638$ \\
Gioi-Omignano & $€ 1,983,852$ \\
Felitto-Roccadaspide & $€ 2,020,590$ \\
Castellabate-Vatolla & $€ 2,032,836$ \\
Teggiano-Padula & $€ 2,118,558$ \\
\hline
\end{tabular}


Table 10. Cont.

\begin{tabular}{cc}
\hline Route Name & Cost of Intervention \\
\hline Castelcivita-Sicignano degli Alburni & $€ 2,265,510$ \\
Trentinara-Stio & $€ 2,461,446$ \\
Acciaroli-Castellabate & $€ 2,632,890$ \\
Pisciotta-Ceraso & $€ 2,926,794$ \\
Sanza-Morigerati & $€ 3,257,436$ \\
Casaletto Spartano-San Giovanni a Piro & $€ 4,555,512$ \\
\hline
\end{tabular}

Table 11 defines the relationship of convenience, of each stretch, between the intervention cost and the potential spillover, in terms of the tourist enhancement of the site, connected to the use of the single stretch. This table defines the goal of the work, that is, the interventions hierarchy.

Table 11. Evaluation of intervention priorities according to the optimization of the cost/impact ratio of the intervention (application to the case study).

\begin{tabular}{lc}
\hline \multicolumn{1}{c}{ Route Name } & Cost/Impact Ratio \\
\hline (1) Prignano Cilento-Cicerale & 16 \\
(2) Ceraso-Vallo della Lucania & 14 \\
(3) Cicerale-Trentinara & 14 \\
(4) Gioi-Omignano & 13 \\
(5) Vallo della Lucania-Gioi & 13 \\
(6) Vatolla-Prignano Cilento & 12 \\
(7) Stio-Felitto & 12 \\
(8) Marina di Camerota-Palinuro & 11 \\
(9) Morigerati-Casaletto Spartano & 11 \\
(10) Palinuro-Pisciotta & 11 \\
(11) Roccadaspide-Castelcivita & 10 \\
(12) Sicignano degli Alburni-Petina & 10 \\
(13) Trentinara-Stio & 10 \\
(14) Felitto-Roccadaspide & 9 \\
(15) Acciaroli-Castellabate & 9 \\
(16) Castelcivita-Sicignano degli Alburni & 8 \\
(17) Castelnuovo Cilento-Marina di C. Velino & 8 \\
(18) Pisciotta-Ceraso & 8 \\
(19) San Giovanni a Piro-Marina di Camerota & 8 \\
(20) Sanza-Morigerati & 7 \\
(21) Casaletto Spartano-San Giovanni a Piro & 7 \\
(22) Castellabate-Vatolla & 7 \\
(23) Teggiano-Padula & 6 \\
\hline
\end{tabular}

\subsection{Phase 6: Model Validation}

The numerical data for the development of the indicators are as follows.

- In order to determine the distance from the coastal strip, the most populated tourist towns of the coastal strip have been taken as reference:

- $\quad$ Agropoli, for the northern area;

- $\quad$ Sapri, for the southern area.

- For inhabitants number, reference was made to the official website of the Campania Region, https://www.tuttitalia.it/campania/.

Table 12 shows the development of the case study data, based on the criteria assumed in paragraph 3.7 (method validation). 
Table 12. Model validation table (implementation of phase 7).

\begin{tabular}{cccc}
\hline Route Name & Cost/ Impact Ratio & Coastal Strip Distance & Inhabitants \\
\hline Prignano Cilento-Cicerale & 16 & 6 & 12 \\
Ceraso-Vallo della Lucania & 14 & 9 & 5 \\
Cicerale-Trentinara & 14 & 8 & 11 \\
Gioi-Omignano & 13 & 10 & 11 \\
Vallo della Lucania-Gioi & 13 & 8 & 6 \\
Vatolla-Prignano Cilento & 12 & 5 & 12 \\
Stio-Felitto & 12 & 11 & 12 \\
Marina di Camerota-Palinuro & 11 & 4 & 10 \\
Morigerati-Casaletto Spartano & 11 & 7 & 12 \\
Palinuro-Pisciotta & 11 & 3 & 10 \\
Roccadaspide-Castelcivita & 10 & 8 & 6 \\
Sicignano degli Alburni-Petina & 10 & 10 & 8 \\
Trentinara-Stio & 10 & 8 & 10 \\
Felitto-Roccadaspide & 9 & 8 & 4 \\
Acciaroli-Castellabate & 9 & 2 & 4 \\
Castelcivita-Sicignano degli Alburni & 8 & 8 & 8 \\
Castelnuovo Cilento-Marina di C. Velino & 8 & 3 & 8 \\
Pisciotta-Ceraso & 8 & 3 & 7 \\
San Giovanni a Piro-Marina di Camerota & 8 & 4 & 7 \\
Sanza-Morigerati & 7 & 7 & 8 \\
Casaletto Spartano-San Giovanni a Piro & 7 & 6 & 7 \\
Castellabate-Vatolla & 7 & 3 & 4 \\
Teggiano-Padula & 6 & 11 & 1 \\
\hline
\end{tabular}

\section{Results and Discussions}

The results of applying the model to the case study can lead to two reading scenarios:

- $1^{\circ}$ Scenario: Overall level of Priority of interventions, according to the route safety (Table 9-Figure 9);

- $\quad 2^{\circ}$ Scenario: Ratio between the intervention cost and the impact in terms of tourism enhancement (Table 11-Figure 10). This last scenario allows to optimize the economic investment according to the greater socio-economic impact of the single intervention.

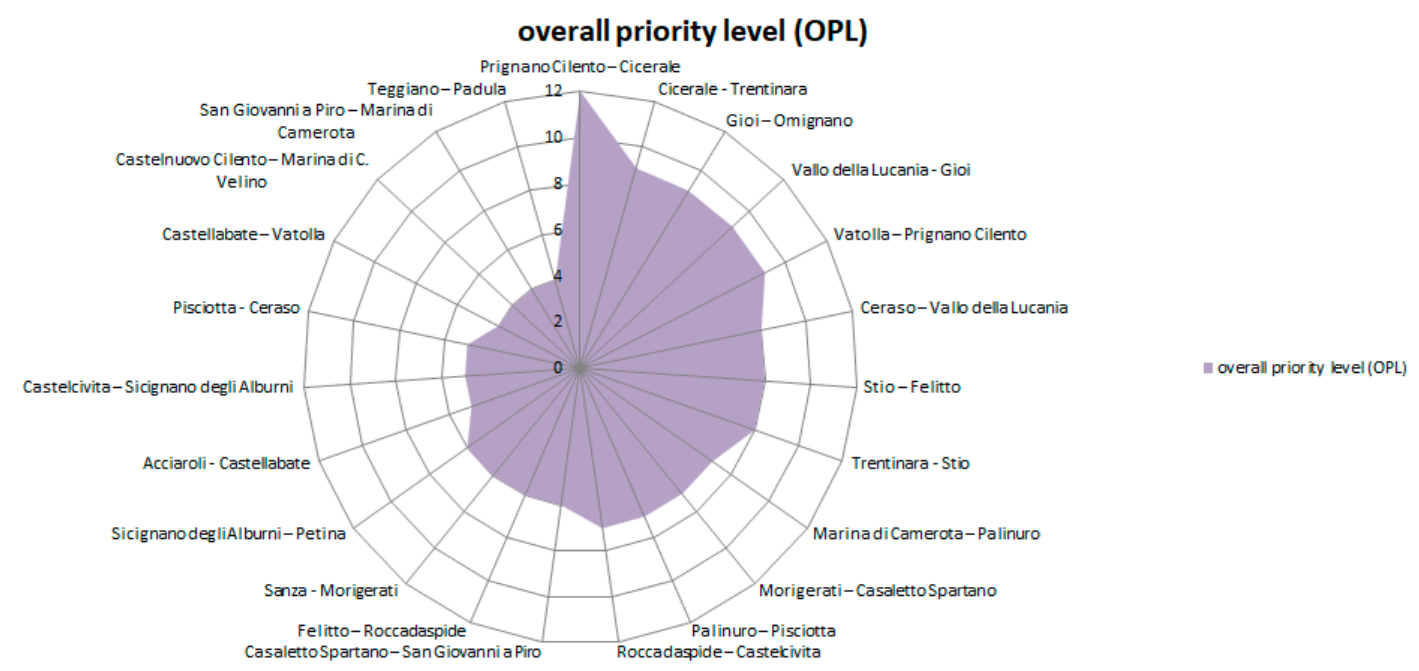

Figure 9. Chart representing the development of the Overall Priority Level (OPL). 


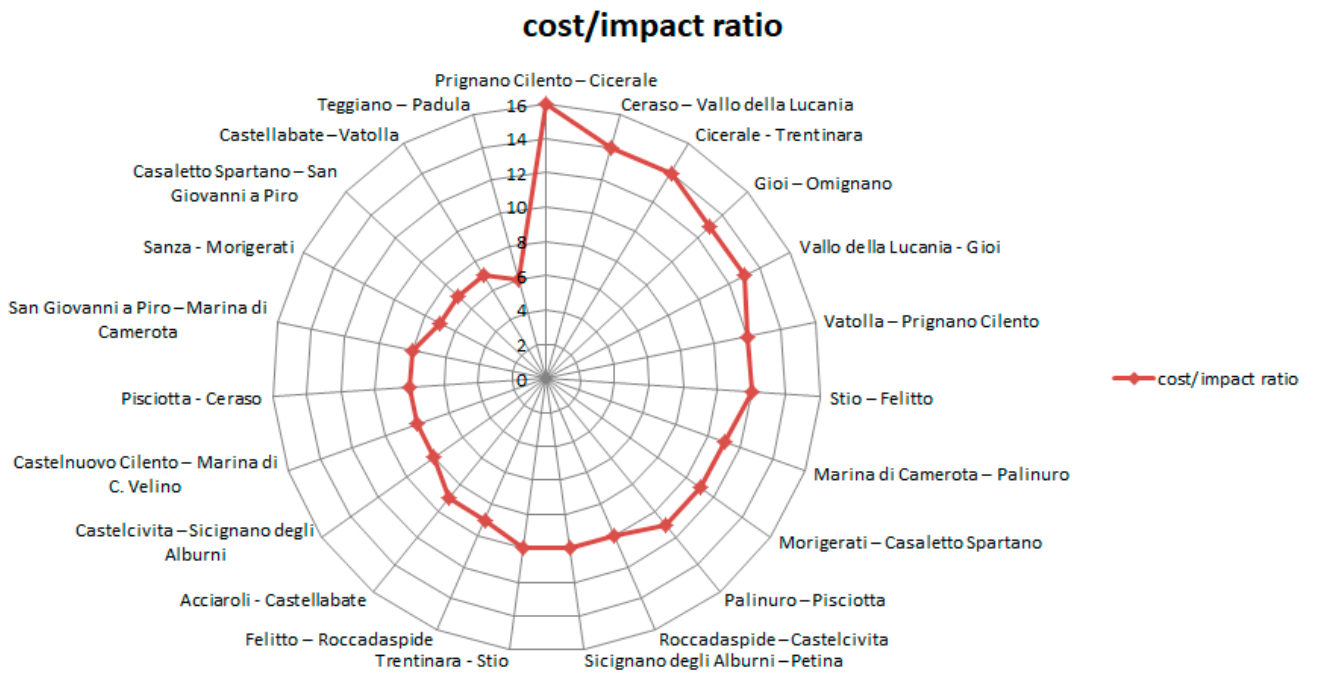

Figure 10. Chart representing the development of the he cost/impact ratio.

Figure 11 shows the model validation, through the verification of the compatibility of the results obtained with two parameters that characterize the level of backwardness and underdevelopment of the town: the greater distance from the coastal strip (an area renowned for its social-economic-environmental virtuosity) and the smaller number of inhabitants.

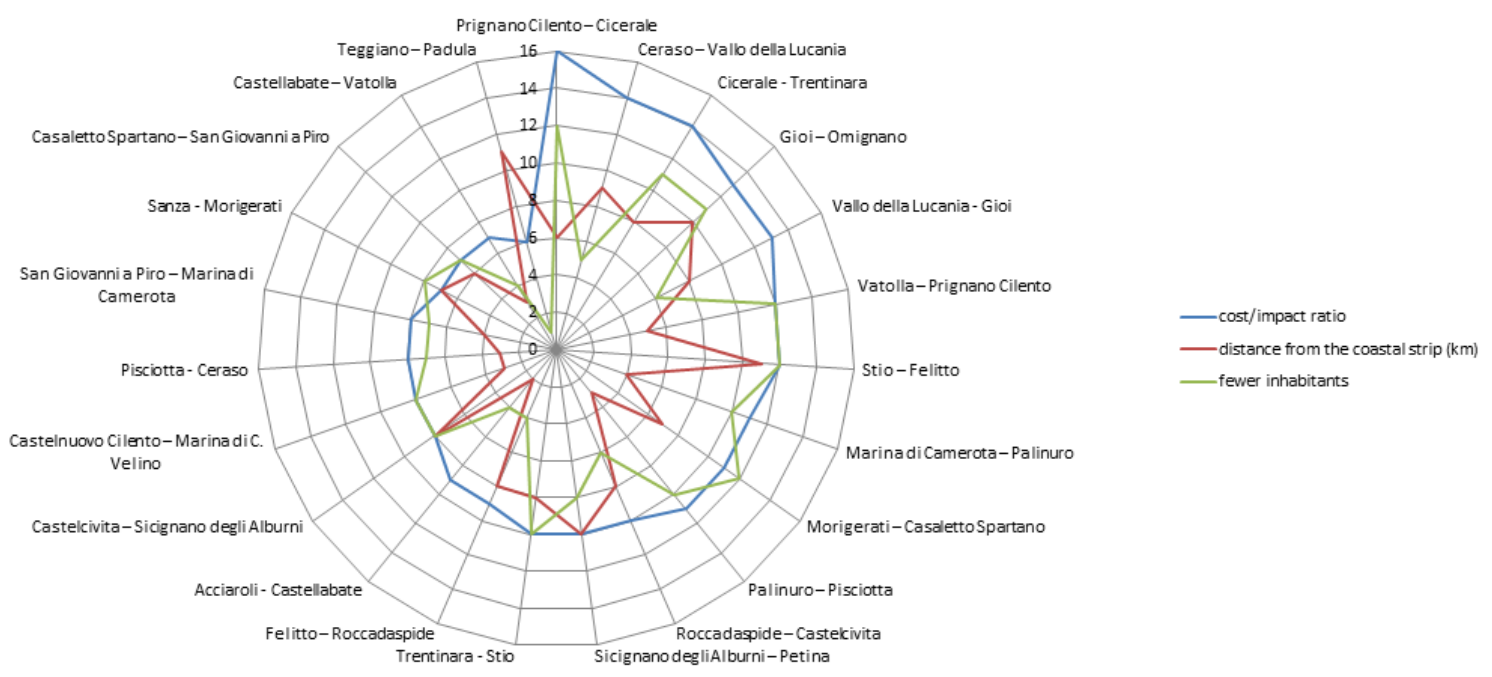

Figure 11. Model validation chart.

The validation of the methodology was carried out by crossing the data resulting from the development of the method with the critical factors of the abandoned towns, that is, greater distance of the town from the coastal strip; fewer inhabitants. Below are the graphs relating to the results.

The results highlight the sense of research, that is, enabling operators in the sector to optimize their investment.

The final ranking (Table 11) shows that the first sections of the overall path are a compromise between the economic viability of the investment (Table 10) and the potential for enhancing the territory, as they can guarantee a greater economic, social and environmental impact in the medium/long term.

In particular, priority is given to Prignano Cilento-Cicerale, Ceraso-Vallo della Lucania, Cicerale-Trentinara sections. This means that the municipalities involved in the above mentioned routes (as start and end of the stage) have better characteristics in terms of interception of international cycling routes, interception of nodes intermodal transport, proximity to UNESCO sites; vice versa, 
they have more critical features, in terms of presence of point-office, presence of local tourist guides associations, tourist-accommodation facilities. The above mentioned ones are the priority sub-interventions, for the above mentioned reasons and in case the overall financing is not available and the intervention has to be managed according to the dynamics of the functional lots.

On the contrary, the sections: Sanza-Morigerati; Casaletto Spartano-San Giovanni a Piro; Castellabate-Vatolla; Teggiano-Padula, are the towns that present less critical situations in terms of resources and accommodation infrastructure. Moreover, these routes are less critical in terms of economic, social and environmental conditions in the considered area. The respective Municipalities involved in these paths embody less potential for improvement, in case of implementation of the intervention, according to a dynamic of allotment of the overall intervention.

The graph in Figure 11 shows that the model is verified: the interventions hierarchy, obtained through the application of the model (Table 11 and Figures 9, 10, 12 and 13) is congruent with the real conditions of backwardness and depopulation of the villages, in terms of greater distance from the most frequented tourist areas (Cilento's coastal strip) and fewer inhabitants (Table 12 and Figure 11).

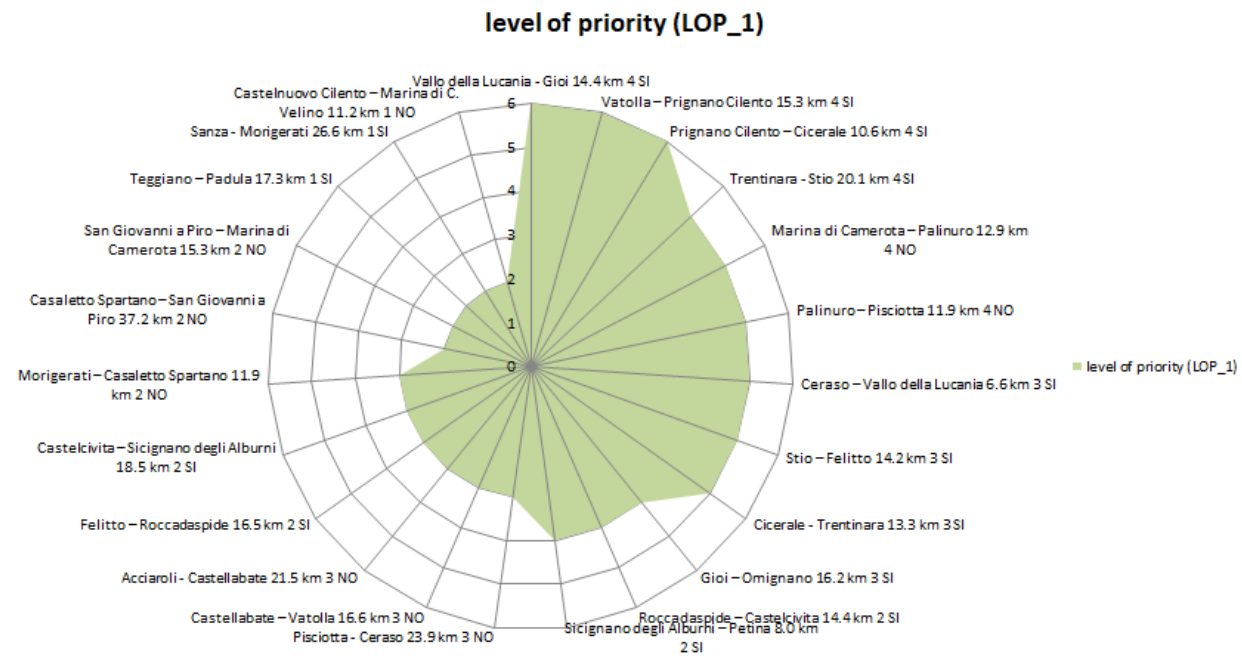

Figure 12. Chart representing the development of Priority Level 1 (LOP_1).

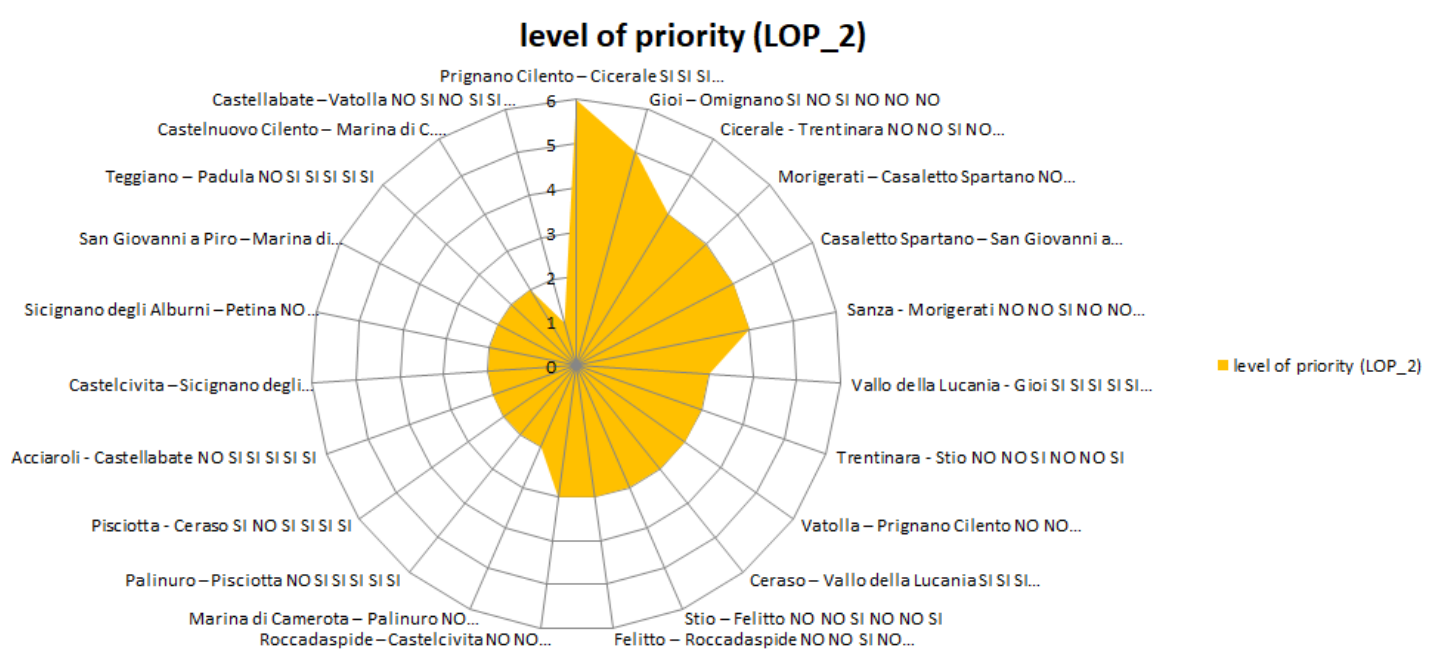

Figure 13. Chart representing the development of Priority Level 2 (LOP_2).

\section{Conclusions}

The aim of the research is the valorization of abandoned areas through sustainable mobility strategies. 
The existence of an adequately signposted path periodically crossed by a flow of visitors who, at "reduced speed," observe, consume, purchase, control, appreciate, can only enhance the areas crossed, even those that are marginal with respect to mass tourism, exerting positive effects on the local economy and encouraging the birth of new entrepreneurial tourism initiatives.

This scenario lends itself to the rise of start-ups and companies, which are essential to provide all the services, supports and comforts necessary to the route users, with consequent positive social and economic spin-offs. In addition to triggering a dynamic of economic development and repopulation of the territory, these operators would also guarantee a preventive action to protect the territory, in terms of its monitoring and control, through the identification and reporting of any critical phenomena (interruptions, landslides, illegal deposit of waste along the route, etc.).

With the implementation of the strategies envisaged, various beneficial effects for the territory are expected:

- enhancement of a portion of the "Inner Cilento" area in Italy;

- $\quad$ expansion of the sustainable tourist offer;

- diffusion of a form of sustainable mobility: "cycling tourism";

- protection, recovery and enhancement of the natural and man-made environment;

- prevention and mitigation of hydrogeological and environmental risk.

The empirical methodology, developed in the present study according to an integrated quali-quantitative approach, has been applied to a design hypothesis of technical and economic feasibility. The objective was to provide a decisional and management tool, to the operators of the sector, aimed at the selection of interventions in the presence of limited budgets [42], through the allotment of a single intervention. The availability of a budget conditions the operation of the public administration, which is forced, most of the time, to split the interventions so that they can be implemented. The study proposes, therefore, a sort of feasibility plan for an intervention that, overall, would cost about $€ 73,476,000$. It is improbable to allocate such an amount in a territorial reality like the South of Italy, if not subdividing it into functional intervention lots.

The elaborated methodology is verified, since (as shown in Figure 11) the graph of the model results overlaps, in a quite clear way, with the criticality of the towns that have determined its underdevelopment [49].

Author Contributions: G.D.R., R.M., B.B. and L.P.I., have designed and structured the article. L.P.I. has deepened the national and international regulatory framework of reference. It has also deepened the framework of the contribution within the international scientific community. G.D.R. defined the objectives, deepened the methodological approach, through the identification of significant indicators and conceived the strategic project hypotheses. L.P.I. and B.B. have also identified the most significant and current bibliographical references for the research. G.D.R., L.P.I., B.B., have carried out the analysis (documentary and field) related to the knowledge of places. R.M. has contributed to the systematization of information and software development. G.D.R. and R.M. have contributed to the development of the method, based on the set objectives and the application of the method to the case studies, through the elaboration of the tables of results. All authors have read and agreed to the published version of the manuscript.

Funding: This research received no external funding.

Acknowledgments: The work developed would not have been possible without the support of the following people: Mario Passannanti Eng., author of a thesis on similar topic, at the University of Salerno; Catello Grimaldi Eng., expert on the subject and practicing sportsman; "Via Silente" association (https://www.laviasilente.it/), for the input of the case study and the concession of the route map; Mauro Luise, expert on the history and traditions of Cilento, owner of the Cilento Club association (https://www.cilentoclub.com/); Assessor Speranza, of the public administration of Novi Velia.

Conflicts of Interest: The authors declare no conflict of interest. 


\section{References}

1. European Week of Regions and Cities. Shrinking Regions-How to Foster Development in Depopulated Areas, Conference in Brussels, 5-9 October 2019. Available online: https://europa.eu/regions-and-cities/ programme/sessions/387_en (accessed on 5 November 2020).

2. Connecting Europe Facility (CEF). Instrument for Strategic Investment in Transport, Energy and Digital Infrastructure. In the Transport Sector. Available online: https:/ec.europa.eu/transport/themes/infrastructure/ cef_en (accessed on 30 September 2020).

3. Strategia Nazionale per le Aree Interne, Governo Italiano Presidenza del Consiglio dei Ministri, Dipartimento per la Programmazione e il Coordinamento Della Politica Economica. Available online: http: //www.programmazioneeconomica.gov.it/2019/05/23/strategia-nazionale-delle-aree-interne/ (accessed on 4 March 2019).

4. Strategia Nazionale Aree Interne, Governo Italiano Presidenza del Consiglio dei Ministri, Agenzia per la Coesione Territoriale. Available online: https://www.agenziacoesione.gov.it/strategia-nazionale-aree-interne/ (accessed on 4 March 2019).

5. Miller, F.; Osbahr, H.; Boyd, E.; Thomalla, F.; Bharwani, S.; Ziervogel, G.; Walker, B.; Birkmann, J.; Van der Leeuw, S.; Rockström, J.; et al. Resilience and vulnerability: Complementary or conflicting concepts? Ecol. Soc. 2010, 15, 11. Available online: http://www.ecologyandsociety.org/vol15/iss3/art11/ (accessed on 10 February 2020). [CrossRef]

6. Fabbricatti, K.; Petroni, M.; Tenore, V. Riattivazione di paesi abbandonati e in via di abbandono: Il Borgo di Carbonara nel Comune di Aquilonia (AV). Sci. Territ. 2016, 4, 180-186.

7. Pinto, M.R.; Viola, S. Cultura materiale e impegno progettuale per il recupero: Living Lab nel Parco del Cilento, Techne. J. Technol. Archit. Environ. 2016, 12, 223-229.

8. Barca, F.; McCann, P.; Rodríguez-Pose, A. The Case for Regional Development Intervention: Place-BASED Versus Place-Neutral Approaches*. J. Reg. Sci. 2012, 52, 134-152. [CrossRef]

9. UNDP. Sustainable Development Goals, No. 11. Available online: http://www.undp.org/content/undp/en/ home/sustainable-development-goals (accessed on 10 February 2020).

10. Raccomandazioni Politiche, Gazzetta Ufficiale dell'Unione Europea, Parere del Comitato Europeo Delle Regioni-Una Tabella di Marcia dell'UE per la Mobilità Ciclistica (2017/C 088/10). Available online: https://eur-lex.europa.eu/legal-content/IT/TXT/?uri=uriserv\%3AOJ.C_.2017.088.01.0049.01.ITA (accessed on 30 September 2020).

11. Serra, M. El cicloturismo y las vías verdes como ejemplo de turismo sostenible. Rev. CIDOB d'Afers Int. 2016, 113, 187-209. [CrossRef]

12. Moral, M.M. El Desarrollo del Cicloturismo Como una Modalidad Turístico Sostenible, Revista Turydes: Turismo y Desarrollo, n.21. Available online: https://www.researchgate.net/publication/312898505 (accessed on 5 October 2020).

13. Ritchie, B.W. Bycicle tourism in the South Island of New Zealand: Planning and management issue. Tour. Manag. 1998, 19, 567-582. [CrossRef]

14. Han, H.; Meng, B.; Kim, W. Bike-traveling as a growing phenomenon: Role of attributes, value, satisfaction, desire, and gender in developing loyalty. Tour. Manag. 2017, 59, 91-103. [CrossRef]

15. Ho, C.-I.; Liao, T.-Y.; Huang, S.-C.; Chen, H.-M. Beyond environmental concerns: Using means-end chains to explore the personal psychological values and motivations of leisure/recreational cyclists. J. Sustain. Tour. 2014, 23, 234-254. [CrossRef]

16. Centre for Sustainability, Tourism and Transport, Breda University of Applied Sciences. Available online: https://www.cstt.nl/projects (accessed on 30 September 2020).

17. Di Marcello, R. I Turismi in Bicicletta Come Strumenti di Sviluppo del Territorio. Analisi e Prospettive in Europa e in Italia; Homeless Book: Faenza, Italy, 2016.

18. Manton, R.; Duggan, A.; Goggins, J.; Clifford, E. Carbon Costs and Savings of Greenways: Creating a balance Sheet for the Sustainable Design and Construction of Cycling Routes. J. Environ. Sustain. Dev. 2014, 13, 3-19. Available online: https://www.researchgate.net/publication/257161333 (accessed on 30 September 2020).

19. Ngo, V.D.; Frank, L.D.; Bigazzi, A.Y. Effects of new urban greenways on transportation energy use and greenhouse gas emissions: A longitudinal study from Vancouver, Canada. Transp. Res. Part D Transp. Environ. 2018, 62, 715-725. [CrossRef] 
20. Manton, R.; Duggan, A.; Goggins, J.; Clifford, E. Use of Carbon Calculation Tools for Sustainable Cycle Network Design. In Proceedings of the Sustainable Development of Energy, Water and Environment Systems, Ohrid, Macedonia, 1-6 July 2012.

21. Hao, L.; Xiao, Z.; Yang, Q. Study on Planning and Construction of Community Greenway for PM2.5 Reduction. Open Fuels Energy Sci. J. 2015, 8, 99-105. [CrossRef]

22. Shahani, F. The Role of Sustainable Greenways in Achievement of Improving the Quality of Life (Tehran's Greenways as a Case Study). In Proceedings of the Fabos Conference on Landscape and Greenway, Amherst, MA, USA, 12-13 April 2013.

23. Fabris, L.M.F.; Semprebon, G. Greenways as a New Potential for Shrinking Cities. The Case of Milan (Italy). In Proceedings of the Fábos Conference on Landscape and Greenway Planning, Amherst, MA, USA, 28-30 March 2019.

24. Dallat, M.A.; Soerjomataram, I.; Hunter, R.; Kee, F. Urban Greenways Have the Potential to Increase Physical Activity Levels Cost-Effectively. Eur. J. Public Health 2013, 24. [CrossRef] [PubMed]

25. Zaręba, A. Greenways Systems in Metropolitan Regions as the Alternative for Sustainable Transport Development, Project: Greenways. Available online: https:/www.researchgate.net/publication/320171891 (accessed on 5 October 2020).

26. Zawawi, A.; Porter, N.; Ives, C. Greenways and Sustainable Urban Mobility Systems. In Humanizing Cities through Car-Free City Development and Transformation; IGI Global: Hershey, PA, USA, 2020. [CrossRef]

27. Quattrone, M.; Tomaselli, G.; Riguccio, L.; Russo, P. Assessment of the territorial suitability for the creation of the greenways networks: Methodological application in the Sicilian landscape context. J. Agric. Eng. 2017, 48. [CrossRef]

28. Dickinson, J.; Lumsdon, L. Slow Travel and Tourism. 2010. Available online: https://www.researchgate.net/ publication/287382696 (accessed on 30 September 2020).

29. Manton, R.; Hynes, S.; Clifford, E. Greenways as a tourism resource: A study of user spending and value. Tour. Plan. Dev. 2016, 13, 427-448. [CrossRef]

30. Tambovceva, T.; Atstaja, D.; Tereshina, M.; Uvarova, I.; Livina, A. Sustainability Challenges and Drivers of Cross-Border Greenway Tourism in Rural Areas. Sustainability 2020, 12, 5927. [CrossRef]

31. Grimaldi, M.; Pellecchia, V.; Fasolino, I. Urban plan and water infrastructures planning: A methodology based on spatial ANP. Sustainability 2017, 9, 771. [CrossRef]

32. Decreto Ministeriale 30 Novembre 1999, n. 557, Regolamento Recante Norme per la Definizione Delle Caratteristiche Tecniche Delle Piste Ciclabili, Ministero dei Lavori Pubblici, Italia. Available online: https://www.gazzettaufficiale.it/eli/id/2000/09/26/000G0315/sg (accessed on 4 March 2019).

33. The Communication from the Commission to the European Parliament, the Council, the European Economic and Social Committee and the Committee of the Regions: "Towards an EU Criminal Policy: Ensuring the effective implementation of EU policies through criminal law". Eur. Crim. Law Rev. 2011, 1, 311-318. [CrossRef]

34. Actors Italia-Attrattori Culturali per il Turismo e l'Occupazione nelle Regioni del Sud Italia. Project Developed by the OECD Center for Local Development in Trento in Cooperation with the Ministry of Cultural Heritage and Activities and Tourism (MIBACT) and the Managing Authority of the Interregional Operational Program "Cultural, Natural and Tourism Attractors" (AdG POIn). Available online: http://www.oecd.org/fr/cfe/leed/trento-mibact-2014-it.htm (accessed on 30 September 2020).

35. Criteri e Tecniche per la Manutenzione del Territorio ai Fini Della Prevenzione del Rischio Idrogeologico, Ministero Dell'ambiente e Della Tutela del Territorio, Italia (maggio 2002). Available online: https://www.minambiente.it/sites/default/files/archivio/allegati/Biblioteca/ds_criteri_ manutenzione_rischio_idrogeologico.pdf (accessed on 5 October 2020).

36. Regolamento per l'Attuazione Degli Interventi di Ingegneria Naturalistica nel Territorio Della Regione Campania. Allegato Tecnico del Regolamento per l'Attuazione degli Interventi di Ingegneria Naturalistica nel Territorio Della Regione Campania. Available online: http://www.sito.regione.campania.it/burc/pdf02/ burcspeciale19_08_02/indice.htm (accessed on 30 September 2020).

37. Ministero dell'Ambiente e della Tutela del Territorio e del Mare-Italia. Piano D'azione per la Sostenibilita' Ambientale dei Consumi nel Settore Della Pubblica Amministrazione (Piano Nazionale D'azione Sul Green Public Procurement-PAN GPP). Available online: https://www.minambiente.it/pagina/piano-dazionenazionale-sul-gpp (accessed on 4 March 2019). 
38. Cellura, T.; Cellura, L. Il Nuovo Manuale dei Criteri Minimi Ambientali in Edilizia; Maggioli Editore: Milano, TX, USA, 2018; pp. 1-17.

39. Panteli, C.; Polycarpou, K.; Morsink-Georgalli, F.Z.; Stasiuliene, L.; Pupeikis, D.; Jurelionis, A.; Fokaides, P.A. Overview of BIM integration into the Construction Sector in European Member States and European Union Acquis. IOP Conf. Ser. Earth Environ. Sci. 2020, 410, 012073. [CrossRef]

40. Decreto Ministeriale, n.560 del 01/12/2017. Definition of the Methods and Timescales for the Progressive Introduction, by the Contracting Stations, the Granting Authorities and Economic Operators, of the Obligatory Use of Specific Electronic Methods and Tools, such as Those of Modelling for Construction and Infrastructure, in the Phases of Design, Construction and Management of the Works and Related Checks-Ministero delle Infrastrutture e dei Trasporti, Italia. Available online: http://www.mit.gov.it/sites/default/files/ media/normativa/2018-01/Decreto\%20Ministro\%20MIT\%20n.\%20560\%20del\%201.12.2017.pdf (accessed on 30 September 2020).

41. Huang, W.C.; Teng, J.Y.; Lin, M.C. The Budget Allocation Model of Public Infrastructure Projects. J. Mar. Sci. Technol. 2010, 18, 697-708.

42. Di Ruocco, G.; Nesticò, A. Archaeological Site Conservation and Enhancement: An Economic Evaluation Model for the Selection of Investment Projects. Sustainability 2018, 10, 3907. [CrossRef]

43. De Brito, M.M.; Evers, M.; Höllermann, B. Prioritization of flood vulnerability, coping capacity and exposure indicators through the Delphi technique: A case study in Taquari-Antas basin, Brazil. Int. J. Disaster Risk Reduct. 2017, 24, 119-128. [CrossRef]

44. Preliminare di Strategia dell'Area Interna "Cilento Interno". Available online: https://www.infocilento.it/ 2019/03/19/cilento-strategia-dellarea-interna-ecco-la-bozza-definitiva/ (accessed on 4 March 2019).

45. Meini, M.; Di Felice, G.; Nocera, R. Resource mapping in the inland areas: Potentiality and critical issues for tourist fruition. Boll. Assoc. Ital. Cartogr. 2017, 4-21. [CrossRef]

46. La via Silente (The Silent Way). Available online: https://www.laviasilente.it/content/ (accessed on 4 March 2019).

47. Giornata Mondiale della Bicicletta, le 5 Piste Ciclabili Più Belle D'italia. Available online: https://www.ohga. it/giornata-mondiale-della-bicicletta-le-5-piste-ciclabili-piu-belle-ditalia/ (accessed on 5 November 2020).

48. Decreto Legislativo 7 Marzo 2018, n. 49-Regulations Containing: “Approval of the Guidelines on how to Carry Out the Functions of the Director of Works and the Director of Execution". Ministero Delle Infrastrutture e dei Trasporti, Italia. Available online: https://www.gazzettaufficiale.it/eli/id/2018/05/15/18G00074/sg (accessed on 2 February 2019).

49. Di Ruocco, G.; Sicignano, E.; Petti, L.; Primicerio, F.; Naddeo, L. Conservation of Building Heritage: The Recovery of the historical centers, of the Cilento and Vallo di Diano. In Proceedings of the Construction Pathology, Rehabilitation Technology and Heritage Management (7th REHABEND Congress), Caceres, Spain, 15-18 May 2018; Available online: https://www.rehabend.unican.es/2018/08_Docs_Varios/00_Book_ of_Abstracts.pdf (accessed on 10 September 2018).

Publisher's Note: MDPI stays neutral with regard to jurisdictional claims in published maps and institutional affiliations.

(C) 2020 by the authors. Licensee MDPI, Basel, Switzerland. This article is an open access article distributed under the terms and conditions of the Creative Commons Attribution (CC BY) license (http://creativecommons.org/licenses/by/4.0/). 